Araştırma Makalesi

\title{
Eleştirel Medya Okuryazarlığı Kapsamında Çocuğa ve Kadına Yönelik Olarak Önerilen Özel Haber Dili
}

\author{
Hicabi Arslan (Dr. Öğr. Üyesi) \\ Adnan Menderes Üniversitesi İletişim Fakültesi \\ harslan@adu.edu.tr
}

Orcid: 0000-0001-9424-7722

Başvuru Tarihi: 09.10.2018

Yayına Kabul Tarihi: 27.12.2018

Yayınlanma Tarihi: 21.01.2019

Öz

Medyada yer alan haberler özellikle kadın ve çocuk şiddet, taciz, tecavüz ve cinayet haberleri kapsamında toplumsal farkındalığı artırmak için yapılan haberler olmasının yanı sıra habere konu olan tarafların yeni medya anlayışı çerçevesinde reyting uğruna etik kurallar çiğnenerek habere dâhil edilmeleri nedeniyle medya ve etik kuralları açısından tartışılması gerekli önemli hususlardır. Genel olarak bakıldığında medyada yer alan haberlerin içerikleri kullanılan dil, kullanılan görseller toplumda ciddi anlamda genel bir kaygı uyandıracak tarzdadır. $\mathrm{Bu}$ çalışmada; çocuk ve kadın temalı haberlerdeki ön yargılı, ötekileștirici, aşağılayıcı, cinsiyetçi ve hedef gösterici dil ve üslubun terkedilerek, aslında nasıl olması gerektiği konusunda bir dizi öneride bulunularak, bu konulara yapıcı bir bakış açısı getirecek yeni bir haber dilinin nasıl olması gerektiği hakkında örnekler üzerinden eğitsel yönlendirmelerde bulunulacaktır. Medyada yer alan haberler özellikle kadın ve çocuk şiddet, taciz, tecavüz ve cinayet haberleri kapsamında toplumsal farkındalığı artırmak için yapılan haberler olmasının yanı sıra habere konu olan tarafların yeni medya anlayışı çerçevesinde reyting uğruna etik kurallar çiğnenerek habere dâhil edilmeleri nedeniyle medya ve etik kuralları açısından tartışılması gerekli önemli hususların ele alınarak bu konuda geliștirilecek olan "yeni haber dili”nin nasıl olması gerektiği konusundaki görüş ve öneriler paylaşllacaktır. Dünya nüfusunun 2/3'nün çocuklardan oluştuğu göz önüne alındığında onlara yönelik olarak yapılacak haberlerin de bir o kadar özenli ve yapıcı nitelikte olması gerekliliğinin yanı sıra Ülkemizdeki kadın-erkek nüfus dengesinin hiç değilse medyada gözetilmesi ve buna uygun haber ve içerik üretilmesi beklenmektedir. Bu konularda atılması gereken adımlarla birlikte çözüm önerileri sunularak, beklenen uzun vadeli ama olumlu sonuçlar üzerinden çalışma detaylandırılacaktır.

Anahtar Kelimeler: Eleştirel Medya Okuryazarlığı, Çocuk, Kadın, Medya, Yeni Haber Dili. 
Research Article

\title{
Specific News Language Suggested Towards Children and Women in The Scope of Critical Media Literacy
}

\author{
Hicabi Arslan (Dr. Öğr. Üyesi) \\ Adnan Menderes Üniversitesi İletişim Fakültesi \\ harslan@adu.edu.tr \\ Orcid: 0000-0001-9424-7722
}

Date Received: 09.10.2018

Date Accepted: 27.12.2018

Date Published: 21.01.2019

\begin{abstract}
News that take place in the media are important issues that should be discussed in terms of media and ethical rules as the parties that are subjected to the news are included by violating the ethical rules in the scope of the new media understanding besides the fact that they are news that are reported to increase public awareness within the context of new concerning women, children, violence, harassment, rape and murder. When it is considered from a general perspective, the language and images that are included in the news of the media are in a manner to arouse a serious concern in the society. In this study; an array of suggestions will be made on leaving the prejudiced, discriminative, gendered and targeting language and tone in the news based on children and women, and how it should be indeed, and educational guidance will be provided through examples regarding how a new news language that would bring a new perspective should be. When it is considered that $2 / 3$ of the world population consisted of children, it is expected that the population balance between women and men in our country should be regarded by the media and in this line, appropriate news and contents should be produced; besides the necessity that the new which will be reported towards children should be diligent and constructive.
\end{abstract}

Suggestions will be proposed with the steps that should be taken in this direction, and the study will be elaborated expected long-term yet positive results.

Keywords: Critical Media Literacy, Child, Woman, Media, New News Language. 


\section{Giriş}

Medya okuryazarlığı konusu ile ilgili literatür incelendiğinde ilk ön plana çıkan nokta 1992 yılındaki Ulusal Medya Okuryazarlığı Öncülük Konferansı'nda (The National Leardership Conference on Media Literacy) geliştirilen ve bu konu üzerindeki akademik ilginin formal bir alana dönüşmesinin başlangıcını olușturan medya okuryazarlığı tanımıdır. Buna göre medya okuryazarlığı: "çeşitli biçimlerde mesajlara ulaşma, analiz etme, değerlendirme ve iletme yeteneğidir (Aufderheide, 1993). Medya okuryazarlığının bireylerin medya tüketiminde daha eleştirel tüketiciler olmaları için bir takım düşünme becerilerine sahip olmaları gerektiği görüşüne dayandığı söylenebilir. Problem çözme, verileri kullanabilme, sorgulama ve ikna etme gibi çeşitli yeterliklerin belirlenmesinde önemli rol oynayan bu becerilerden birisi de eleştirel düşünmedir. Eleștirel düşünme, olayların nedenleri ve sonuçlarını geçerli ve güvenilir verilere dayandırarak açıklamaya çalışan ve temelde "neden" sorusuna yanıt arayan bir düşünme becerisidir. Eleștirel düşünme ve medya okuryazarlığı kavramlarının kapsamı incelendiğinde, iki kavram arasında ortak özelliklerin olduğu görülmektedir. Bu durum, bu iki kavram arasında nasıl ve ne yönde bir ilişkinin olduğu sorusunu akla getirmektedir.

Günlük yaşantımızın bir parçası haline gelen elektronik iletişim araçları (internet, bilgisayar, cep telefonu, oyun konsolları, ipod v.b.) yeni medya olarak anılmaktadır. Yeni medyanın geleneksel medyadan (gazete, radyo, televizyon, sinema) ayrilan temel özellikleri ise etkileşimli ve çokluortam biçemine sahip olması, çok sayıda bilgiyi aynı anda aktarabilmesi, farklı iletişim boyutlarının aynı anda gerçekleşmesini sağlamasıdır (Binark ve Bek, 2007, 5). Medyanın bu imkanlarının yanı sıra artan çeşitliliği ve bu çeşitliliğin her yaştaki bireyi etkilemesi ise medya okuryazarlığı kavramını ortaya çıkarmıştır.

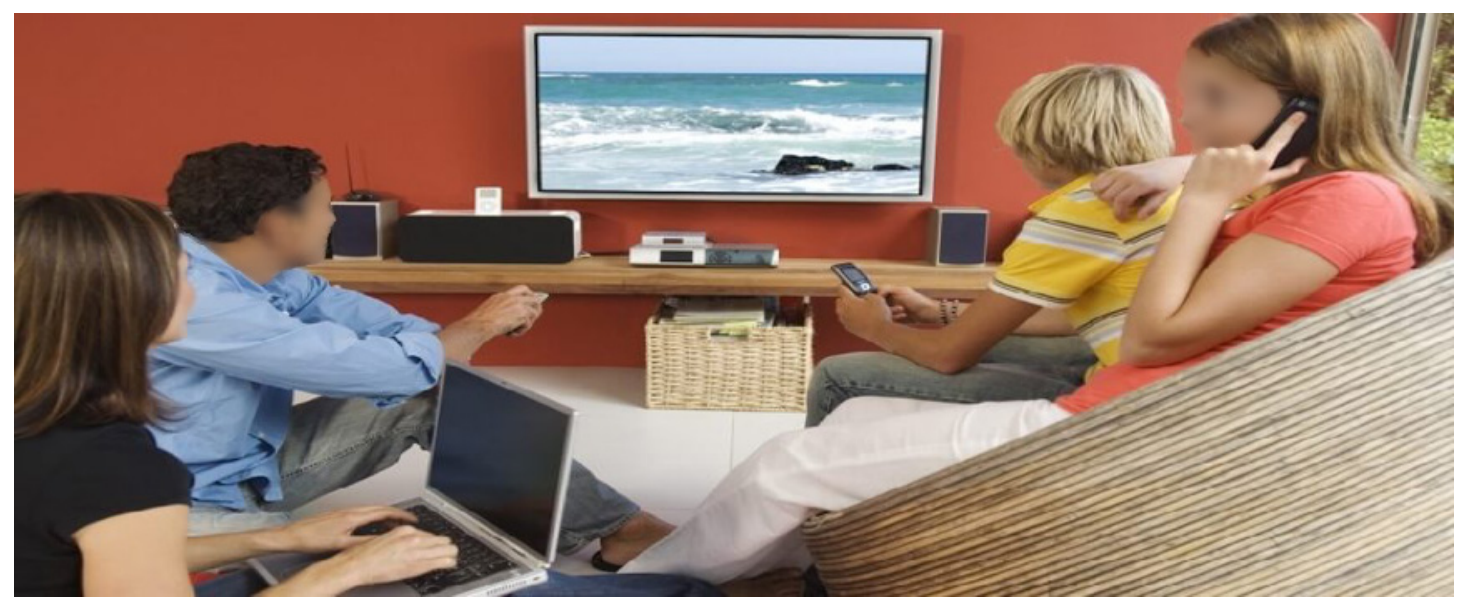

Resim 1: (http://www.webbilge.net/kitle-iletisim-araclarininaile-uzerinde-etkisi/-erişim tarihi 27.09.2018)

Medyanın hayatımıza girmesiyle birlikte bireyler toplumsal yaşamı bu araçlar aracılığı ile algılamaya başlamışlar ve doğal olarak bu "aracıların" gerçekliğine bağımlı hale gelmişlerdir. Medya günümüzde toplumsal yaşamı belirleyen en önemli merkezlerden biridir. Kaçıncı güç olduğu çeşitli tartışmalara konu olsa da sosyal yaşamın en önemli aktörlerinden biri olduğu ve modern dünyada pek çok insanın yaşamı medya aracılığıyla algıladığı bilinir. İletişim olanaklarının çoğalması ile kişiler arası ilişkilerin yerini medyalar aracılığı ile gerçekleșen iletişim almıştır. Bu da, toplumun medyalara olan ihtiyacının artması ve onları hayatının merkezine alması 
sonucunu beraberinde getirmiştir. İnsanlar medyalar aracılığı ile sosyalleşmekte, haberdar olmakta, eğitilmekte ve eğlenmektedir artık. Neredeyse yaşamı medyalar aracılığı ile yaşamak gibi bir kaçınılmazla karşı karşıyadır modern insan bugün. Özellikle televizyon seyretmek dünyanın pek çok yerinde en yaygın serbest zaman etkinliğidir. Günde en azından 3-4 saatini ekran karşısında geçirmeyen insan sayısı çok azdır, bu konuda yapılmış araştırmalar özellikle Türkiye'nin bu konuda dünyada başı çektiğini göstermektedir.

Öncelikle, medya okuryazarlığını "gerçek" anlamıyla düşünmeye başlamalıyız. Çünkü bir çok insan, "okuryazar" olmayı basılı dokümanlarda yazılı olan ifadelerdeki yüzeysel anlamı okuyabilme olarak algılamaktadır. Bu sınırlı ve eski bakış açısı, iletişim araçlarının çeşitlenmesiyle birlikte yetersiz kalmıştır. Medya okuryazarlığının bir de "yazma" boyutu vardır. Bu da iletişim sürecinin doğasıyla ilgili bir durumdur.

Medya okuryazarlığı kavramının ortaya çıkışından bu yana konuya farklı açılardan bakan bir çok görüş olmuştur. İletişim veya ilgili alanlarda çalışanlar medya okuryazarlığını, kişilerin mesleğe yönelik bilgi ve becerileri edindikleri bir "mesleki eğitim" olarak algılarken, diğer bazıları da yeni medyayı (dijital medyayı) kullanma becerilerindeki yeterlilik olarak görmektedirler.

\section{Eleştirel Medya Okuryazarlığının İçeriği}

Medyanın etik ilkelere bağlı olması gerektiği konusunda gerek meslek örgütleri, gerek sivil toplum kuruluşları ve gerekse de hükümetler çeşitli çalışmalarla, medya kuruluşlarındaki özdenetim olanaklarını arttırma ve bireyleri medyanın etkilerine karşı daha dirençli kılma yönünde ciddi adımlar atmışlardır. Tüm bu çalışmaların öncelikli hedefi, geniş halk kitlelerinin sürekli maruz kaldıkları medya mesajlarıyla ilgili olarak bilgilendirmek ve böylesine önemli bir işlevi olan medya kuruluşların daha doğru ve sorumlu yayıncılığa teşvik etmektir (Radyo ve Televizyon Üst Kurulu [RTÜK], 2007, 33).

Gündelik yaşamın ayrılmaz bir parçası haline gelen kitle iletişim araçlarından ihtiyaç duyulan faydayı temin etmek ve gelebilecek zararları da asgariye indirmek gerekir. Bunun yanı sıra kitle iletişiminin soğuk yüzüne karşılık yüz yüze iletişimin sıcaklığının fark edilmesi, kişilerarası ilişkilerin geliştirilmesi ve sürdürülebilmesi bakımından önemlidir.

Eleştirel düşünme boyutunda, medya okuryazarlığının temel amacının yaratıcı ve eleştirel düşünme becerilerini geliştirmek olduğu, medya ve televizyon eleştirisi yapmanın bunu güçlendirdiği, multimedya alanlarında mesaj üretmeyi, kavramayı, yorumlamayı ve analiz etmeyi içerdiği ve medya okuryazarlığı kavramının sadece televizyon, film izlemek olmadığı, internet temelli kritik bir çerçeveyi de sunduğu ifade edilmektedir (Barut ve Koç, 2016, 599).

İçerik açısından eleştirel medya okuryazarlığı dört ana başlık altında izlenebilir;

- İstenen bilgiye erişim

- Elde edilen bilgiyi çözümleme

- Verileri değerlendirme

- Bu verilerden üretim yapma

Bu içerik ele alınırken; erişilmiş olan bir bilginin kişi ya da kişiler üzerinde hangi etkileri bıraktığı ve nasıl bir ortam içerisinde değerlendirildiği de önemlidir. 
- Teknolojik ölçütlerde değerlendirme

- Psikolojik ve biyolojik ölçütlerde değerlendirme

- Görsel ölçütlerde değerlendirme

- Değerler, yargılar ve diğer ölçütlerde değerlendirme

Medya okuryazarlığının sahip olduğu bazı temel ilkeler vardır, bunlar;

- Medya okuryazarlığı bir özellik değildir

- Medya okuryazarı bir birey beceri ve alışkanlıklarını sürekli yenilemeli ve geliştirmelidir

- Medya okuryazarı olaylara geniş bir açıdan bakmalı ve kısır döngülerden uzak durmalıdır

- Medya okuryazarı kişisel konularda, kendisinin ve hedef kitlenin konumunu ayırt edebilmelidir ve tarafsızlığını korumalıdır

Temel tanımı bakımından medya okuryazarlığı, medyanın akıllı ve etkili bir biçimde kullanılabilmesini vurgulamaktadır. Medyayı teşkil eden ve içerikleri oluşturan yapılar ile bu sistemlerin siyasi yaklaşımlarını, gelişimlerini, ekonomik yapılarını, yönetim yapılarını ve kaynakları hakkında bilgi sahibi olmak demektir (Orhon, 2011, 379).

Medya okuryazarlığını ısı ölçere benzer, her birey ısı ölçerin dereceleri üzerinde bir yer işgal etmektedir. Bunun nedeni ise görsel açıdan zenginleștirilmiş bilgi ortamlarıyla karşı karşıya gelen bireyler için doğru medya aracını, doğru mesaj aktarımı için kullanabilme becerisinin öneminden kaynaklanmaktadır. Bu görüş, medya okuryazarlığıyla medya mesajları hakkında bilinçli bir kamuoyu oluşturulmasının amaçlandığının temel bir göstergesi olarak kabul edilebilir. $\mathrm{Bu}$ bilgilere dayanarak medya okuryazarlığının amacının, bireyin medya mesajlarını doğru anlayabilmesine olanak sağlayacak bir medya bilincinin oluşturulması ve bu doğrultuda medya kültürünü çözümleyen, eleştirel bir bakış açısı kazandırabilmek olduğu söylenebilir.

Medyanın hem bireyler ve hem de çocuklar üzerindeki etkisi oldukça fazladır. Özellikle sosyal medyanın etkisi her geçen gün daha da artmakta, hayatın bir parçası olan her türlü şiddet ve olumsuzluğu da adeta meşrulaştırmakta ve tüketici konumunda olan çocuk yaştaki takipçileri etkisi altına alarak pasifize etmektedir.

Medya tüketicilerini hangi yașta olursa olsun, pasif tüketiciler ve aktif tüketiciler olarak ikiye ayırabiliriz. Pasif tüketiciler, izleyen, dinleyen, okuyan olarak sadece içeriği tüketenlerdir. Aktif tüketiciler ise telefon ve internet üzerinden oyun oynayarak veya sosyal medyada yer alarak iletişime katılımcı olarak iştirak ederler. Bize göre, medya tüketimini birey kendi bilinçli tercihi ile yapabiliyorsa ve istediği anda sonlandırabiliyorsa bağımlı olduğu söylenemez. Ancak işini, okulunu, uykusunu ihmal edecek oranda teknoloji tüketimine ihtiyaç hissediyorsa burada bağımlılıktan söz edebiliriz (Mora, 2014, 21).

Medya ve etik alanında yapılan çalışmalarda genel olarak medyanın yapılan haberlerde tiraj kaygısı nedeniyle içeriklerinde sansasyonel, aşırı duygusal tarzda haberlere ağırlık verildiği gözlenmektedir. Özellikle sosyal medya kullanımının yaygınlaşmaya başlaması ile medya okuryazarlı̆̆ı eğitimine önem verilmesi gerekliliği ortadadır. Geleneksel medyadan yeni medyaya geçişte yaşananlar global 
bir köy olduğumuzu kanıtlar niteliktedir. Ancak bu köyün içerisinde bazen özel hayatın duvarları yıkılarak herkesin her şeyi bilmesi yaşamlara derin yıkımlar da yaşatabilmektedir. Artık gizlilik dediğimiz kavramın pek de kolay korunamadığı ortadır. Ancak gazeteci ve okurun karşılıklı olarak hakların kullanımı özellikle yeni medya düzeni içerisinde medya etiği kavramının öneminin giderek artan boyutta olduğunun da göstergesidir. Gittikçe artan kadın ve çocuk cinayetlerinin toplumda farkındalığı artırmak, toplum yararına sorumlulukların yerine getirilmesi adına habere konu olması gazetecilik mesleği açısından son derece olağandır.

Geleneksel medya ile yeni medya arasındaki farka bakıldığında; değişimin boyutları çok net bir şekilde kendini göstermektedir.

Tablo 1: Yeni Medya ile geleneksel medya arasındaki farklılıklar-Celalettin Aktaş

\begin{tabular}{|l|l|l|}
\hline & Geleneksel Medya & Yeni Medya \\
\hline Kanal & Az sayıda & Çok sayıda \\
\hline Kontrol & Gönderen & Alıcı \\
\hline İletim & Tek yönlü & İki yönlü, etkileşimli \\
\hline İçerik & Sınırlı & Çeşitlendirilmiş \\
\hline Kapsama Alanı & Bölgesel, küresel & Küresel \\
\hline Toplumsal Kontrol & $\begin{array}{l}\text { Kanunlar, meslek ve } \\
\text { ahlâk ilkeleri, halk eğitimi }\end{array}$ & Teknik aygıtlar, izleme \\
\hline Zaman & Senkron & Asenkron \\
\hline Yapısı & $\begin{array}{l}\text { Merkeziyetçi (bir } \\
\text { noktadan-çok noktaya) }\end{array}$ & $\begin{array}{l}\text { Merkeziyetçi olmayan (çok } \\
\text { noktadan-çok noktaya) }\end{array}$ \\
\hline
\end{tabular}

Medya okuryazarı her bir birey;

- Medyayı bilinçli, etkili ve kendi yararı için kullanır. Alternatif bilgi kaynakları arar, farklı kaynaklardan gelen bilginin doğruluğunu değerlendirir.

- Medyanın bireylerin ve toplumların inanç, tavir, davranışlar ve değerler üzerindeki etkisinin bilincindedir. Medyanın fikir, bilgi ve haberi bir başkasının bakış açısıyla aktardığının farkındadır.

- Medyayı kültürü anlamada kaynak olarak görür. Medyanın kendine özgü bir dili olduğunu bilir. Medya karşısında eleștireldir. Bilgiye ulaşma ve kullanmada etik ve yasal konuları bilir.

Medya okuryazarlığının içeriği ile ilgilenen birinin muhtemelen şu soruları sorması beklenir:

- Medya okuryazarlığı nedir? Medya okuryazarlığı ne tür özellikler içermektedir?

- Eleştirel düşünme nedir? Eleştirel düşünen bireylerin özellikleri nelerdir?

- Medya okuryazarlığı ve eleştirel düşünme arasında kavramsal çerçevede nasıl bir ilișki vardır?

$\mathrm{Bu}$ soruların cevabına ulaşan ve karşılığını bulan her birey aşağıda sıralanmış özelliklere sahip bir medya okuryazarı özelliğini de kazanır.

- Medyayı doğru okuyarak yaşadığı çevreye duyarlı, ülkesinin problemlerini bilen, medyada gördüklerini aklın süzgecinden geçirecek düzeyde bilinç kazanır.

- Televizyon, video, sinema, reklâm, internet gibi ortamlardaki mesajlara ulaşarak bunları çözümleme, değerlendirme ve iletme yeteneği elde eder. 
- Yazılı, görsel, işitsel medyaya yönelik eleştirel bakış açısı kazanır.

- Mesajların oluşturulmasına ve analizine dönük olarak cevap bulmaktan soru sorma sürecine doğru bir değişimi gündeme getirir.

- Bilinçli bir medya okuryazarı olur.

- Toplumsal yaşama daha aktif ve yapıcı șekilde katılır.

- Kamu ve özel yayıncılığın daha olumlu noktalara taşınması noktasında duyarlılık oluşturulmasına katkı sağlar.

\section{Medya ve Etik}

Günümüzün gelişmiş kitle iletişim araçları, gündelik yaşamımızın vazgeçilmezleridir. Hayatımızı çok yönlü etkileyen bu araçlar, getirdikleri olumlu katkılarla, birlikte aynı zamanda yarattıkları olumsuz toplumsal ve bireysel etkilerle de en fazla tartıșılan konuların başında gelmektedir. Bu tartışmaların odağında da iletişim ve medya etiği yer almaktadır (Örs, 2016, 11). Günümüzde hâkim olan medya etiği anlayışının temel gerilim, bireysel tarzdaki bir profesyonel etikle, medya kuruluşlarının karşı karşıya olduğu, piyasanın ve siyasetin gerçekleri arasındaki çatışmadan kaynaklanmaktadır. Medyada etik tavır için moral bir temel geliştirme çabaları genellikle, kamunun bilme hakkı ya da bireyin mahremiyet hakkıyla ilişkili standart bir pratik ya da özgül bir karar karşısında; Gazeteci bireyin konumunu kişisel bir vicdan sorunu etrafında tartışmaya çalışmakla sınırlı kalmaktadır. Geleneksel medyada etik ya da farklı bir tabirle iletişim etiği kavramıla ise gazetecilik, televizyon, radyo gibi kuruluşlarda faaliyet gösteren insanların mesleki etik kuralları karşılanmaktadır. Toplumun genelini ilgilendirmesi gereken etik kavramının özellikle iletişim sektöründe önem kazanması ise gazetecilik faaliyetinin özüyle ilgilidir.

Ahlak ve etik kavramları arasındaki ilişki, benzerlik ve farklılıklara gelince; ahlak, "belli bir dönemde belli insan topluluklarınca benimsenmiş olan, bireylerin birbirleriyle olan ilişkilerini düzenleyen törel davranış kurallarının, yasalarının, ilkelerinin toplamıdır." Tanımdan da anlaşılacağı üzere ahlakın en belirgin özelliği göreceli olmasıdır. Ahlak, hem yere ve zamana göre hem de toplumdan topluma değişebileceği gibi aynı toplum içinde farklı ahlak anlayışına sahip kesimler de bulunabilir. Ahlak felsefesi olarak da bilinen etik ise insan davranışlarını, yargılarını, davranış kurallarını ve ilkelerini ahlakilik temelinde araştıran, savunan ya da eleștiren bir felsefe dalıdır. "Ahlak ve etik arasındaki ilişki, birinin toplumun ve insanın vicdanı ile ilgili bir olgu olması, diğerinin ise, bununla ilgili felsefeyi temsil etmesiyle açıklanabilir." Geleneksel medyada etik ya da farklı bir tabirle iletişim etiği kavramıyla ise gazetecilik, televizyon, radyo gibi kuruluşlarda faaliyet gösteren insanların mesleki etik kuralları karşılanmaktadır. Toplumun genelini ilgilendirmesi gereken etik kavramının özellikle iletişim sektöründe önem kazanması ise gazetecilik faaliyetinin özüyle ilgilidir.

Geleneksel medyadaki etik sorunlar devam ederken yeni medyanın ve onun içinde yer alan sosyal medyanın insanların hayatlarına girmesi hatta hayatlarının tam orta yerinde, merkezde yer almasıyla beraber, bu alanda da etik sorunlar baş göstermiş ve gündeme gelmeye başlamıştır. Özel yaşamın gizliliği başta olmak üzere, haber metinlerinin içeriği, görseller, telif hakları, kullanıcının çok fazla reklamsal içeriğe maruz kalması, genel ahlaka aykırı paylaşımlar vb. gibi daha pek çok etik sorunlar sosyal medya için tartışılmaktadır. 


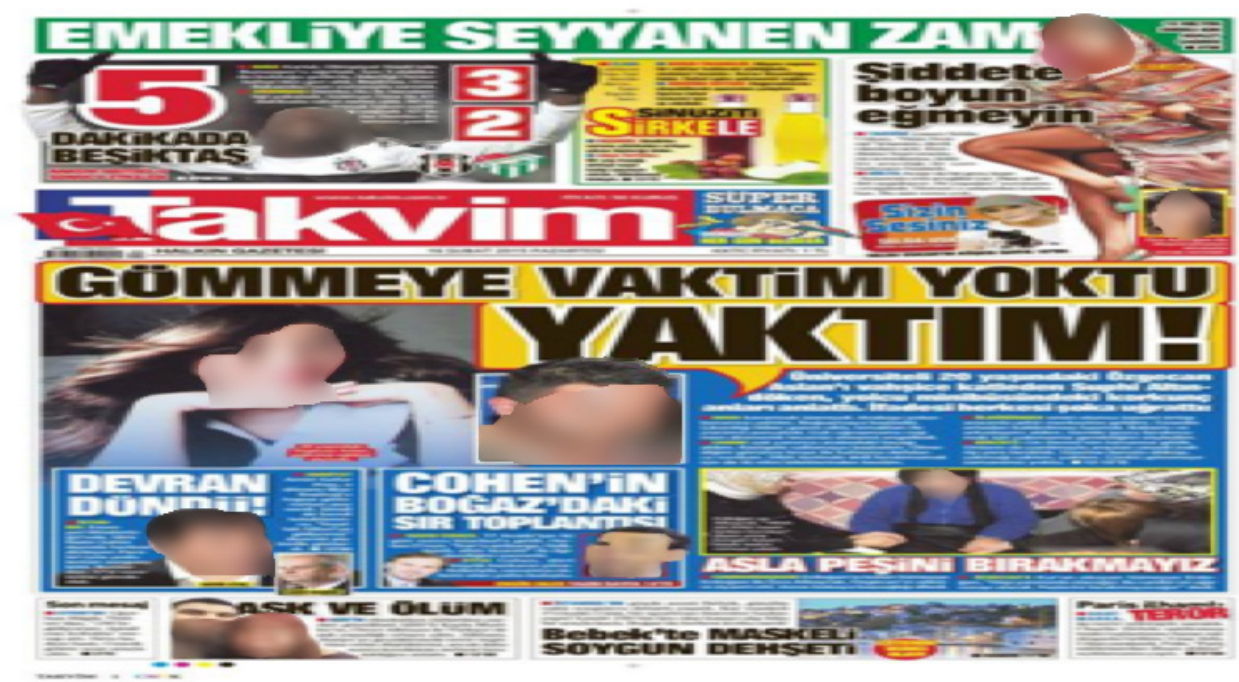

Resim 2: (https://www.takvim.com.tr/guncel/2015/02/16/ vahset-minibusu, erişim tarihi 28.09.2018)

Özellikle yeni medya dahil olmak üzere etik ihlallerinin tespitine yönelik olarak soru ve sorunlar şu şekilde sıralanmıştır (Binark ve Bayraktutan, 2013, 39):

- Özel yaşamın gizliliği

- Telif/patent hakları

- İçeriğin asıl kaynağının gösterilmemesi

- Üretilen içeriklerin olgunlaşmadan ve doğruluğunun teyidinin yapılmadan yayılması

- Kișisel verilerin güvenliğinin sağlanamaması

- Veri madenciliği

- Dijital gözetim

- Haber ve ticari enformasyonun sınırlarının belirsizleşmesi

- Yeni medya ortamındaki yoğun reklam içeriği

- Yanıltıcı etiketleme ve başlıklandırma

- Nefret söylemi

- Bireyin yeni medya ortamında sadece tüketici olarak konumlandırılması

Medyada etik denetimi sağlamak kamu vicdanı ile sınırlı olmayıp aynı zamanda bunu sağlayan oluşumlar da mevuttur. Bunlar Ombudsmanlık ve Okur -İzleyici -Takipçi Temsilcilikleridir.

\subsection{Ombudsmanlık ve Etik}

Ombudsmanlık kurumu, ilke ve kaideleri kendisine referans almakta, bunları da çalışma yöntemlerine uygulamaktadır. Dolayısıyla örgütleri dışarıdan denetleyen bir mekanizma olarak ombudsman, örgütlerde etik değer, ilke ve kuralların benimsenmesinde ve kurumsallaşmasında önemli bir yere ve göreve sahiptir. Bu amaçla;

- Kurumlarda etik kültürünü yerleştirmek ve geliştirmek

- Çalışanların etik davranış ilkeleri konusunda karşılaştıkları sorunlarla ilgili olarak onlara tavsiyelerde bulunmak

- Yapılmış olan tüm etik uygulamaları olumlu-olumsuz yönleriyle değerlendirme 
Günümüz ombudsmanlık kurumu/kurumlarının kullanabileceği en etkili yollardan birisi de medyadır. Ombudsman medya üzerinden raporlama ve faaliyetlerini duyururken diğer yandan da kendisine gelen şikayet ve eleştirileri derleyerek bunun medya aracılığı ile ilgili idare üzerinde bir kamuoyu baskısı oluşmasını sağlar. Medya ile yürütülen bu ilişki doğal olarak ombudsman kurumunun daha şeffaf ve halka açık bir şekilde faaliyet göstermesinin de önünü açmış olacak.

\subsection{Okur-İzleyici-Takipçi Temsilciliği ve Etik}

Kitle iletişim araçlarında okur temsilcisi (ombudsman) görevlendirilmesi, gerek görsel-işitsel gerekse yazılı basın alanında özdenetimi sağlayarak buna hız kazandıracak olumlu bir uygulamadır. Ancak bu özdenetim görevini sürdürürken ombudsmanlar zaman zaman bazı tepkilerle karşılaşabilmektedir. İş güvenliği açısından ise bir ombudsmanın durumu endişe verici olabilmektedir. Çünkü ombudsman içinde bulunduğu kurumla ve/veya gazetecilerle ilgili şikayetleri değerlendirip, eğer varsa hataları da ortaya koyup eleştirirken, bu görevi ne kadar tarafsız ve hoşgörülü bir yaklaşımla yapsa da aynı kurumda çalışan meslektaşlarının ister istemez tepkisini çekebilir (Özgen, 2003, 31). Medya ve beraberinde getirdiği çok seslilik, son yıllarda medyada meydana gelen ekonomik dönüşüm ve beraberinde getirdiği işadamı-gazeteci kimliğine bir tepki ve aynı zamanda çözüm niteliği taşımaktadır. Görece küçük ölçekli yeni medya kurumları ana akım medya ile iktidar arasındaki ekonomik ilişkilerden bağımsız faaliyet gösterdiği, her düşünceye yer verdiği ve tüm kullanıcılara demokratik bir biçimde düşüncelerini paylaşma imkânı verdiği için yeni ve korunması gerekli bir özgürlük alanı yaratmaktadır. $\mathrm{Bu}$ alanın verimli ve demokrasiyi geliştirici bir nitelik taşıması ise yoğun denetim mekanizmaları ve hukuki yaptırımlar çerçevesinde değil kullanıcıların önemli bir toplumsal kurum haline gelen medya konusunda bilinçlendirilmesi ve medyanın doğru analizi ile mümkün olacaktır.

Gazetecilikte etiği genel etik kurallarından somutlamak mümkün değildir. Ancak her meslekte olduğu gibi gazeteciliğin de kendine özgü etik ilke ve kuralları vardır. Gazetecilikte geçerli olması istenen temel ahlak kurallarının yazıya dökülmesi genellikle meslek örgütlerinin kurulmasıyla başlamıștır. 1900'lü yılların bașında kurulmaya başlayan sendikalar, dernekler gibi mesleki örgütler yayınladıkları bildirilerde temek mesleki ahlak kurallarından söz etmişlerdir. Daha sonraki yıllarda gazeteler de sadece kendi kurumlarını ve çalışanlarını bağlayan gazetecilik mesleğiyle ilgili, kendilerine özgü ahlak kuralları saptama yolunu izlemişlerdir (Atabek, 2006, 8).

Basın İlan Kurumu Genel Kurulu'nun, 20 Mayıs 1964 tarihinde aldığı 25 no’lu kararda, "Basın Ahlak Esasları" şöyle belirlenmiştir:

“Madde 1- 195 sayılı Kanun’un 49. maddesinde sözü edilen (Basın Ahlak Esasları) aşağıda gösterilmiştir:

1. Bir amme müessesesi olan gazetecilik mesleği, bu mesleğin dişında kalan özel ya da ahlaka aykırı maksat ve menfaatlere alet edilemez ve amme menfaatlerine zarar verici bir şekilde kullanılamaz.

2. Yazı, haber, fotoğraf ve sair şekillerde yapılacak yayınlarda, şu hususlara riayet edilir:

a) Ahlaka aykırı ya da müstehcen yayında bulunulamaz. 
b) Şahıs, müessese ve zümreleri hedef tutan yazılarda, galiz kelimeler kullanılamaz, şeref ve haysiyetlere karşı haksız yayın yapılamaz.

c) Amme menfaatini ilgilendirmeyen hallerde, fertlerin hususi hayatları, küçük düşürücü şekilde teşhir edilemez.

d) Şahıslar, müesseseler ya da zümreler aleyhinde iftira ve isnatta bulunulamaz.

e) Din istismar edilemez.

3. Haberlerde ve olayların yorumunda hakikatlerden tahrif ya da kısaltma yoluyla maksatlı olarak ayrılınamaz, doğruluğu şüphe uyandırabilen ve tahkiki gazetecilik imkanları içinde bulunan haberler, tahkik edilmeden ve doğruluğuna emin olunmadan yazılamaz.

4. Gazetenin ya da gazetecinin şahsi ya da taraf tutan kanaatlerine, haberlerin metninde yer verilemez.

5. Haber başlıklarında, haberin ihtiva ettiği hususlar tahrif edilemez.

6. Amme menfaati mutlak lüzum göstermedikçe, "mahrem" kaydıyla verilen malumat yayımlanamaz.

7. Gazeteci, kaynakların mahremiyetini koruyacak ve kendisine verilen sırlara saygı gösterecektir.

8. Haber, yazı ya da resim kaynaklarının, yayın tarihi için koydukları zaman kaydı ihlal edilemez.

9. İlan, reklam mahiyetindeki haber, resim ya da yazıların, ilan ya da reklam olduğu, tereddüde yer bırakmayacak şekilde belirtilir.

10. Mevkutelerin verdikleri yanlış bilgilerden dolayı yollanacak haklı cevap ya da tekzipler, cevap ya da tekzibe neden olan yazının tesirini tamamıla giderecek şekilde, en kısa bir zamanda yayımlanır.

11. Yazı, haber, fotoğraf ve sair şekillerde yapılacak yayınların kaynaklarıyla, kadro mensupları, baskı ya da fiili satış adedi okuyucuya açıklanmak istendiği takdirde yanlış ya da yanıltıcı bilgi verilemez.

Yukarıda gazetecilik mesleğine ilişkin olarak bazı kurum ve kuruluşların ahlak ve meslek etiğine ilişkin olarak belirtmiş oldukları esaslar medyada üretim yapan diğer alanlarda da geçerliliğini korumaktadır. Gazetecilikte mesleki etik kurallarına ve ilkelerine işlerlik kazandırmak hukuk ve özdenetim olmak üzere iki șekilde gerçekleştirilmektedir. Özdenetim, "mesleki saygınlığı sağlamak, doğru, güvenilir haber vermek, yorumları inanılır kılmak, okuyucunun güvenini sürdürmek için yapılması ve yapılmaması gerekenlerin bütünüdür". Özdenetim yöntemleri basını özgür, demokratik rejimlerle yönetilen ülkelerde söz konusudur. Basın özgürlügünün kötüye kullanılmasını ve devletin basına müdahalesini önlemek için, bir başka deyişle özgür, sorumlu ve sorunsuz bir basın için özdenetim anlayışı ve özdenetim kurumları doğmuştur (Çakır, 2017, 67). 


\section{Haberlerde Çocuğun Temsiline Eleştirel Bakış - Çocuk Odaklı Habercilik}

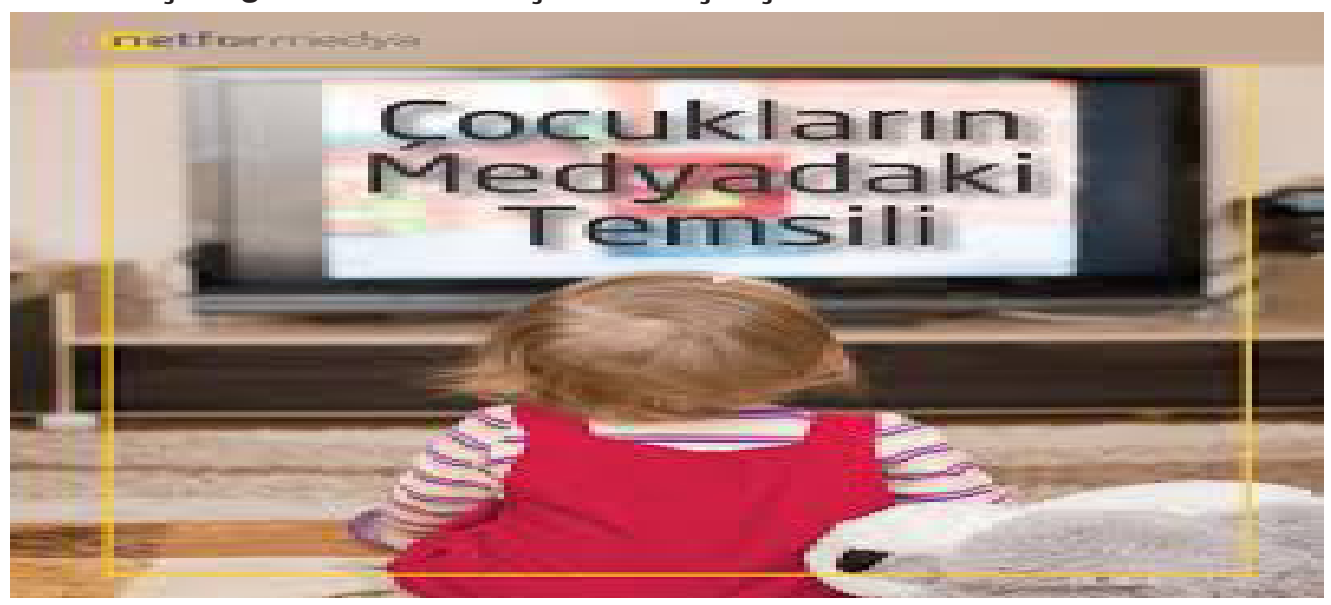

Resim 3: (https://twitter.com/netfordergi, erişim tarihi 28.09.2018)

Medya okuryazarı bir bireyin sahip olması gereken bu özelliklere göre bir medya okuryazarı, medyayı amaçlı bir biçimde seçer, kullanır, geçerli ve güvenilir bilgiye ulaşmaya çalışır. Medyadaki mesajlarının, planlı bir çalışmanın sonucunda ortaya çıktığını ve medya mesajlarının hangi araçlar kullanılarak hangi amaçlarla yapılandırıldığının farkında olan medya okuryazarı, bu yönüyle sorgulayıcı davranışlar gösterir. Farklı kaynaklardan sınırsız sayıda mesaj iletiminin gerçekleştiği günümüzde, medya mesajlarının doğru biçimde anlaşılabilmesi, yorumlanabilmesi ve kullanılabilmesi, bilinçli bir medya tüketicisi olma açısından oldukça önemlidir. Nitekim bu alanda yapılan çalıșmalar, bilinçli bir medya okuryazarı olmanın önemini vurgulamaktadır.

Örneğin reklamlar, çocuk programları, çizgi filmler ve diziler gibi medya içeriğinin İnternet, cep telefonları gibi teknolojilerin, okuma kitaplarının, eğitim sisteminin ve ailenin sosyo-ekonomik düzeyinin çocuklar üzerindeki etkisinin bütün yönleriyle tartışıldığı 4. Uluslararası Çocuk ve İletişim Kongresi'nde, en çok 5 ile 15 yaş arasındaki çocukların risk altında olduğu, çünkü en çok ilgilenilmesi gereken yaşta televizyon ve İnternetle tanıştıkları, anne ve babanın da çocuğun risk altında olduğunun farkında olmadığı, anne babaların çocuğu nu bu tür tehlikelerden koruma yollarını bilmedikleri belirtilmiştir.

Tek başına hiçbir iletişim aracı çocuğu yetiștirmeye ne ehildir, ne de sosyalleşmeyi gerçekleştirecek kadar olgunlaşmıştır. Bu nedenle hiçbir iletişim aracı çocuğun sosyalleşmesi ve entelektüel düzeyinden sorumlu tutulamaz. Görsel iletişim araçlarının çocukların ve gençlerin psikososyal gelişimlerini özendirici değil, engelleyici yönleri olduğu yönündeki görüşü de gözden uzak tutmamak gerekir (Şirin, 2011,12).

Anlam ve ideolojiyi yeniden üreten bir araç olan medya hem içerik üreten hem de üretilmiş olan içeriği pazarlayan bir araçtır. Medya ürünlerini pazarlarken hedef kitleyi etkileyebilecek mesajlar üretilmektedir. Mesajların kabul görmesi amacıyla da mesaja uygun sosyal tipler ve kișilerden medya yararlanmaktadır. Bu bağlamda, çocuğun medya ürünleri içerisinde yer alması veya piyasaya sürülen ürünlerin pazarlanmasında çocuktan yararlanılmasını da görmek mümkündür. Beslendikleri ideolojik ve siyasal kaynaklar farklı olmasına karşın medya genellikle aynı şekilde çocuğa yaklaşmaktadır. Bu durum medyanın yekpare olduğu anlamına gelmemektedir. 
Çocukların haberlerde temsili daha çok "mağdur çocuk" tanımlamasıyla karşımıza çıkmaktadır. Çocuk ve medya tartışması yapılan çalışmalarda, genellikle çocukların medyanın olumsuz etkilerini ve çocukların hangi medya mecralarını takip ettiğini tespit etmeyi amaçladığı görülmektedir. Sosyolojik çalışmaların çocuk algısının yetişkin merkezli olmasın edeniyle genellikle çocukların konu edinmesi üç şekilde olmaktadır. Birincisi, çocukların yetişkinler için tehdit olarak ele alınması, ikinci olarak çocukların yetişkinlerin kurbanı olarak ele alınması ve üçüncü olarak ise kültürün öğrencisi yani sosyalleşme bağlamında ele alınması (Kitzinger, 1988, 8586) olarak görülmektedir.

Uluslararası Gazeteciler Federasyonu'nun (FIJ) “Medyada Çocuk Haklarını Tanıtmak” konulu bir atölye çalışmasında belirtildiğine göre; çocuklar dünya nüfusunun üçte ikisinden fazlasını oluşturdukları halde, medyanın kapsadığı konuların yüzde beşlinden azı çocuklarla ilgili. Medya çocukları haber konusu yaptığında ise, bu "çocuk fuhuşu, organ kaçakçılığı, cinsel istismar, eğitim ve sağlık hizmetlerinden mahrum bırakılmaları, çocuk emeği sömürüsü, sokak çocuklar, yakınlar tarafından cinsel taciz, babanın (ensest) ya da öğretmenlerin cinsel tacizi" gibi konularda oluyor. Çocukların haber medyasında temsil edilmesi açısından ülkemizdeki durum, gelişmekte olan ülkelerinkine benzerdir. Öyle ki; çocukların medyada temsil edilmeleri halinde dahi bir ayrımcılıktan söz etmek mümkün olabiliyor.

Gülgün Erdoğan Tosun'un yazısında kullandığı kaynaklardan örneklediği gibi, dünyanın her yerinde "sokakta yaşayan ya da çalışan çocuklar", "sokak çocukları" benzeri genelleyici sözcüklerle anılıyorlar: İngiltere'de onlara "yabanileşmiş (feral) çocuklar" deniliyor. Kolombiya'da "yatak böcekleri”, Ruanda'da "kötü çocuklar", Kamerun'da “sinekler”, Vietnam'da “toz böcekleri”, Brezilya'da "marjinaller” deniliyor ve Tosun'un dikkat çektiği gibi bunların hepsinde ortak tema -varsıl olmadıkları kesin olan bu çocukların- «haşereyle bir tutulmaları» (Alankuş, 2012, 34).

Çocuklarla ilgili haber yaparken takip edilmesi gereken ana başlıkları bulmak ve uygulamak aynı zamanda bu alanda uyulması gereken etik ilkeleri de uygulamak anlamına gelmektedir. Bu konuda gösterilecek hassasiyet o haberlere konu olan çocukların ve sosyal çevrelerinin de korunması anlamını taşır. Örneğin aşağıda görseli bulunan ve 28.08.2018 tarihli Hürriyet Gazetesi'nde yer alan "Evli Çocuklarla İlgili Flaş Gelişme” başlıklı haberin başlığı ve görseli ile haberin detayı incelendiğinde başlık ve görselde daha titiz davranılması gerekliliği ortaya çıkmaktadır.

Haber; "Kimliklerinde yanlışlıkla evli yazılan Suriyeli 4 kardeşin "Boşanmak istiyoruz" isyanı duyuldu. Yaşları 8 ile 17 arası değișen 4 kardeșin 'Evli' yazan hatalı kimlikleri düzeltildi” şeklinde detaylandırılmasa okuyucuyu, takipçiyi "çocuk yaşta yapılan-yaptırılan bir evlilik" gibi yanlış bir algıya götürebilir 


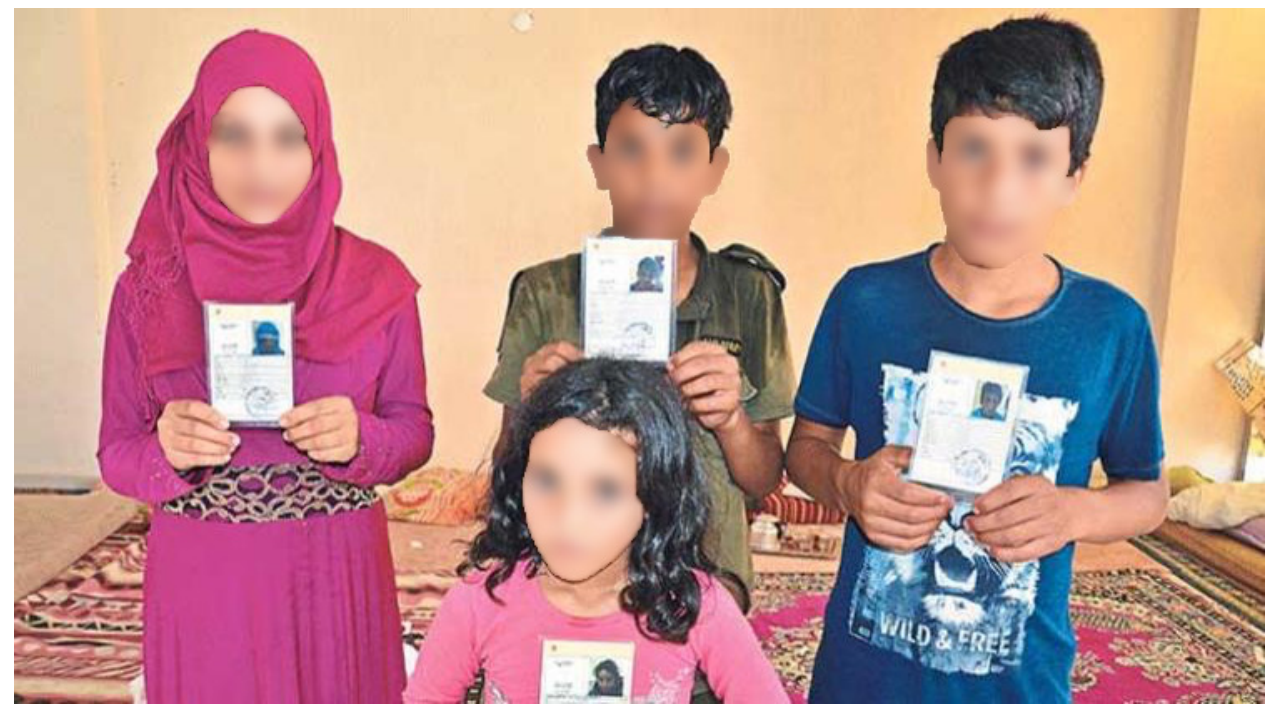

Resim 4: (http://www.hurriyet.com.tr/gundem/evli-cocuklarlailgili-flas-gelisme-40938852- erişim tarihi:02.10.2018)

2001 yılında Seul'daki yıllık kongreden sonra benimsenen temel ilkelere göre (Bek, 2011, 28):

- Çocuklarla ilgili herhangi bir materyalin yol açabileceği sonuçları önceden titizlikle gözetmek ve böylece çocukların maruz kalabilecekleri zararı asgari düzeyde tutmak;

- Bunun kamu yararına olacağına ilişkin netveriler bulunmadıkça, ilgili çocukların görsel sunumundan ve çocukların teşhisine imkân verecek yollardan kaçınmak;

- Mümkün olduğu durumlarda ve herhangi bir zorlama olmaksızın, çocuklara kendi görüşlerini ifade etmek üzere medyaya erişim imkânları sağlamak;

- Çocuklar tarafından sağlanan bilgilerin bağımsız yollardan teyidini sağlamak ve bu teyit işleminin bilgi veren çocukları riske sokmadan gerçekleşmesini güvence altına almak;

- Çocukların cinsellik içeren görüntülerini kullanmaktan kaçınmak;

- Resimler bulurken adil, açık ve doğrudan yöntemlere baş- vurmak ve mümkün olduğu durumlarda bu resimleri çocukların veya sorumlu bir yetişkin veya vasi/ nezaretçinin bilgisi ve onayı dahilinde elde etmek;

- Çocuklar adına konuştuğunu veya çocukların çıkarlarını gözettiğini iddia eden kuruluşların konum ve durumlarını doğrulatmak;

- Çocuğa yarar sağlayacağının açıkça görüldüğü durumlar dışında, çocukların esenliği ile ilgili materyaller karşısında çocuklara veya çocukların ana-babalarına veya vasilerine herhangi bir ödeme yapmamak.

Medyayı; çocukları da üretim sürecine katarak içerik belirleme ve onların yararına olacak biçimde yeniden şekillendirme için öncelikle asıl hedefin belirlenmesi gereklidir. Burada medya kuruluşlarına düşen temel görevler ve medyada görev yapan profesyonellere düșen temel görevler olmak üzere 2 temel bașlık altında konu ele alınmalıdır. Bu aşamaları gerçekleştirirken de şu uyarılar göz ardı edilmemelidir:

- Üretim esnasında dikkat edilmesi gereken konular titizlikle belirlenmeli

- Çocukların üretilen ürünün içeriğine dahil olması için katılım programı planlanmalı 
- Üretimin asıl hedef kitlesi olan çocuklarla istenilen sonuca ulaşabilmek için nasıl bir işbirliği içinde olunacağının sınırları çizilmeli

Bunlar belirlenirken;

- Çocuklara medyanın teknolojik altyapı içerisinde neleri sunabileceği gösterilmeli

- Gelişme dönemleri itibariyle neyin, ne kadar miktarda ve ne kadar süreyle tüketileceği konusunda bilinçlendirme eğitimi verilmeli

- Zihinsel alan, duygusal alan, fiziksel alan hakkında çocuklara bilgilendirme yapılarak onların savunma mekanizmalarını geliștirmesine yardımcı olunmalı

Milliyet Gazetesi'nin çocuk haklarıve hak haberciliği konusunda görüşlerini özetlediği "Ombudsman Görüşü" başlıklı satırlar, bize bu konuda farkındalık oluşturması ve yön göstermesi için atılacak adımları da aslında özetlemiş oluyor:

Çocuklarla ilgili haberlerde medyanın sorumluluğu yetişkinlere oranla tartışmasız çok daha fazla ve öncelikli olmalıdır. Çocuklara yönelik istismar alanlarının başında cinsellik ve suça itilme olgusu geliyor. Milliyet'i de, mesleki etik kodları olan dünyanın saygın gazete ve televizyonlarını da 'çocuk hakları' konusunda bağlayan özellikle isim, görüntü konusundaki ihlalleri önleyen kurallar bulunmakta. Çocuklara zarar verici ve BBC'nin tanımıyla 'gücendirici' yayınlardan kaçınırken sadece önleyici olmak, negatif haberlerde kaçınmak yetmiyor. Yeni akım medyanın 'çocuk odaklı habercilik' üzerine de kendini geliştirmesi gerekiyor. Çocuk İhmal ve İstismarını Önleme Platformu'nun yeni ilkelerle ortaya çıkarak, projeksiyonu medyaya çevirmesi çok önemlidir. Sivil toplum örgütleri çocuklar adına bu taramayı yaptıkça, medya da eleştiri ve önerilerden yararlanacaktır.

Milliyet'te bu duygunun çok baskın olduğunu biliyorum. Çocuk edebiyatının saygın ismi Yalvaç Ural'ın haftada bir çocuklar için yaptığı özel sayfadan sonra Miço ekini yeniden yayımlamaya başlamıştır.

$\mathrm{Bu}$ gazetenin 'okur yetiştirmeye' verdiği önemin göstergesidir. Ombudsman olarak, bu sayfanın 'yayın politikasına giren alanlarda öneride bulunmaktan öte bir misyonu olmadığının bilinciyle, 'Çocuk hakları sayfası' açılması isteğini kadın okurlarımızdan gelen açıklama doğrultusunda Milliyet Genel Yayın Yönetmeni Tayfun Devecioğlu'nun dikkatine sunuyorum. Platformun değerli üyelerine teşekkür ederiz. (http://www.milliyet.com.tr/cocuk-haklari-sayfasi/ombudsman/ haberdetay/12.07.2010/1262334/default.htm- erişim tarihi:02.10.2018)

Gerek ombudsman görüşü, gerekse okur-izleyici-takipçi temsilcisi görüşü olsun hepsinin ortak noktası medyadaki içerik ve bunun yeterliliği konusudur. 0 zaman sorulması gereken sorular ve aranacak cevaplar da ortak kaygıyı taşımalıdır:

- Medya çocukla ilgili haberleri hazırlarken çocuğun (kendi öncelikli) yüksek yararını gözetiyor mu?

- Habere konu olan çocuklar, haberde görünür kılınmalı mıdır?

- Medya dilinin çocukla ilgili mağduriyet haberlerindeki önemi nedir?

- Sansasyonel haberlere konu olan çocukların durumu takip ediliyor mu?

- Cocuk haberleri hak temelli yapıliyor mu? 
- Çocuk haberlerinin 'Hak haberleri' başlıklı bir sayfada 2-3 günde bir toplu olarak verilmesi neden önemlidir?

- Çocuk mağduriyetini kanıksatmamak için haberleri hangi ifadelerle vermek daha uygundur?

- Medya olaylar konusunda bilirkişi ve uzman arayıșında nelere dikkat etmeli ve olayların tekrarını önlemek için ne yapmalı?

- Tek suçlu arama kolaycılığının etkileri çocuk mağduriyetini nasıl etkiliyor?

- Çocuk suçlarının ne olduğu toplumca paylaşılmalı mıdır?

- Dünya ile karşılaştırmalı sunumlar neden önemlidir?

\section{Haberlerde Kadının Temsiline Eleştirel Bakış - Kadın Odakı Habercilik}

İnsanlık tarihinin çatışmalarla dolu olduğu dikkate alınırsa şiddetin bir çözüm aracı olarak kullanıldığını söylemek yanlış olmaz. Bu bağlamda tarihsel süreçte gerek cinsiyet açısından, gerekse toprak elde etme konusunda kullanılan şiddet, sürekli eşitsizlik yaratmıştır. Bu noktada şiddeti uygulayan ve şiddeti gören kategorilerine bakıldığında güçlünün güçsüze uyguladığı bir durumla karşılaşılmaktadır. Bu durum yapısal bir özellik göstermekte ve şiddetin şiddet doğurmasına yol açmakta ve toplumda bir şiddet döngüsünün kendisini üretmesine neden olmaktadır. Kadın tıpkı çocuk gibi kitle iletişim araçlarında ya hiç yer almıyor, görmezden geliniyor ya da ataerkil uygulamalarla üretilen ön yargılarla karşımıza çıkartılıyor. Pek çok başarılı işleri yerine getirmelerine rağmen kadınlar, meslekleri ve becerileriyle medyada çok az yer bulmakta, yer aldıklarında ise başarılarının yerine çoğunlukla yaşamları, dış görünüşleri, düşünceleri ve sosyal çevreleri ile öne çıkmaktalar.

Ataerkil kültürel değerler kapsamında erkeğin kadına zorla sözünü dinlettirmesi de kadına yönelik şiddet kapsamındadır. Bir başka ifadeyle kadın kendi iradesinin dışında istemediği bir davranışa erkek tarafından zorlandığında (örneğin kocası, babası, ağabeyi, akraba erkekler ya da tanımadığı erkeklerin kendi sözünü dinletmek için kadına ısrarlı davranışta bulunması gibi) kadın şiddete maruz kalmaktadır (Baran ve diğerleri, 2017,109) Kadına ve çocuğa yönelik şiddet, taciz, tecavüz, cinayet haberleri sosyal medyada, yazılı basında yer alan haberlerden daha yoğun bir şekilde karşımıza çıkmaktadır. Bir gazete haberine göre o gazetenin internet sayfasında aynı haberin daha detaylı bir şekilde işlendiği görülebilmektedir. Yaşanan cinayeti haberleştirirken suçlunun ağzından tüm yaşananları olduğu gibi okura aktarmak hem mağdur ailelerini hem de toplum vicdanını ciddi anlamda yaralayacaktır. Böyle haberler yapılırken olası yeni mağduriyetlerin önüne geçilmeye çalışılması gerekirken aslında mağdur yakınlarının bu detayları öğrendikten sonra suçlunun yakınlarına kin güderek öç alma girişimi içerisine girme ihtimalleri de unutulmamalıdır.

Aşağıda yerel bir gazetenin internet sayfasında yayınlanan bu haberde, cinayet nedeniyle mağdur olan tarafın intikam duygusu içerisinde hareket ederek işlediği iddia edilen yeni bir eylemden, suçtan söz edilmektedir. Bu şekilde yorumlanarak verilen haberler, kısır döngü içerisinde yeni olayların, suçların ayak sesleri olabilmektedir.

“Kocasını öldüren kadının ailesine intikam bombası Adana'da geçtiğimiz ay eşini öldüren Çilem Karabulut'un baba evine bombalı saldırı düzenlendi. Sabah erken saatlerdeki saldırıda bomba duvara çarparak yere düştü. 
Saldırıda ölen ya da yaralanan olmazken maddi hasar meydana geldi." (https://www.haber46.com.tr/guncel/kocasini-olduren-kadinin-ailesine-intikambombasi-h111335.html- erișim tarihi:02.10.2018)

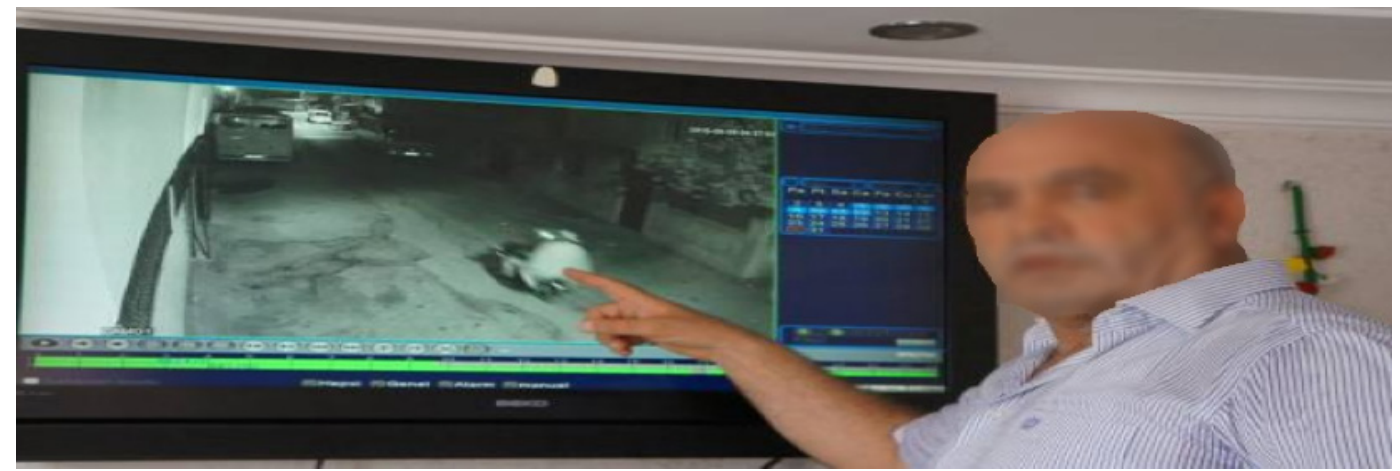

Resim 5: (https://www.haber46.com.tr/guncel/kocasini-olduren-kadininailesine-intikam-bombasi-h111335.html erişim tarihi:02.10.2018)

Türkiye Çağdaş Gazeteciler Cemiyeti tarafından "Toplumsal Cinsiyet Eşitlikçi Haber Kılavuzu" adlı kitapta;

"Mağduru mağdur etmemek, mağduru değil faili teşhir etmek ilkesinden hareketle yapılması gerekenler...

- Haber fail ifadesine dayanarak yazılmamalı, ölen kadının katilin/failin iddialarını yanıtlayacak ve çürütecek durumda olmadığı unutulmamalı.

- Haber verilirken söylentilerden, yakıştırmalardan, kalıplaşmış söylemlerden ve önyargılardan uzak durulmalı.

- Melodram, sansasyon ve pornografiden kaçınılmalı. Cinayetin ayrıntılarını pornografik olarak resmederek şiddetin pornografisi üretilmemeli.

- Haber metni, cinayeti dramatize eden unsurlar taşımamalı.

- "Gizli aşk", "yasak aşk", "çılgın aşk" gibi tanımlamalardan kaçınılmalı.

- Cinsel saldırı eyleminin ayrıntıları belirtilmemeli, öykülenmemeli.

- Mağdurkadınları yakınlarının da zarar görebileceğigözönünde bulundurularak, adres mahalle, semt yer bilgisi verilmemeli.

- Cinsel saldırı haberleri reyting/ tiraj yarışından muaf tutulmalı." şeklinde maddeler halinde ifade edilmiştir ( Türkiye Gazeteciler Cemiyeti [TGC], 2016, 6366-67-68).

Medyada, kadın bedeni aracılığıyla sürdürülen cinsiyet politikasının bir sonucu olarak toplum nezdinde erkekler 'haber, tartışma, yorum vb..' gibi ciddi içeriğe yönelik programları, kadınlar ise pembe dizi, reality show, yarışma-eğlence gibi hafif içeriğe sahip programları izlerler anlamı taşıyan genel bir algı oluşmuştur. Günümüzde halen kadınların bir çoğu cinsellik, aldatılma, kıskançlık gibi haberlere konu olarak medyada kendilerine yer bulabilmektedir. Kadınlar ülkenin siyasal ya da ekonomik gündeminden soyutlanmış olarak en çok da aldatan-aldatılan konumlarıyla gündeme gelmektedir. Bu bağlamda öncelikli olarak kadınların bilinçlendirilmesi gerekmektedir. Ancak kadınların yanı sıra erkeklerin de eğitilmesi, kadına bakış açılarının değiştirilmesi açısından son derece önemlidir. Kadın konuları özellikle kadın medya çalışanları tarafından daha fazla gündeme taşınmalı ve kadınların meta olarak kullanılması durumu bir an önce değiştirilmelidir. Sonuç olarak medyada 
kadın olgusunun kullanımında kadınların sadece cinsellikleriyle değil siyasetten ekonomiye, kültür-sanattan spora toplumun çeşitli alanlarındaki başarılarıyla yansitılmasına dikkat edilmelidir.

Türk Medyasında kadının sunumu ve yaratılan algılarla ilgili verdiğim bu örnek en basitlerinden bir tanesidir. Asıl sorun kadın-beden-temsil-siyaset başlıklarının yarattığı iki ayrı temsil problemini içerisinde barındırmaktadır. Kadın ve medya ilişkisinin sorunlu niteliği 'medya ve kadın' sözcüklerinin bir arada kullanıldığı hemen her durumda ortaya çıkmaktadır. Bunu bütünleyen ikincil sorun alanı ise medyada kadınların 'beden' erkeklerin ise 'akıl' üzerinden temsil edilmeleridir. Başka bir söyleyiş biçimiyle kadınların kendi içlerinde belli başlı tutarsızlıklar, çelişkiler taşıdıkları bundan hareketle belirlenmiş basılı kalıplar halinde temsil edildikleri bunun da ataerkil günlük yaşam ilişkilerini yeniden üretme sürecine araç edildiği sonucuna ulaşabiliriz. Kısacası kadının medyadaki temsil siyaseti olarak adlandırılan bu durum geçmişten günümüze işlevsel olan bir toplumsal süreci desteklemekten ileriye gidememektedir (https://medium.com/turkce/t\%C3\%BCrkmedyas\%C4\%B1nda-kad\%C4\%B1n\%C4\%B1n-temsili-sorunu-c5729dff652-erişim tarihi:02.10.2018).

Medya sahip olduğu güç ile toplumsal cinsiyet eşitsizliğini düzeltmeli ve gerekli atarak kadının yerini pozitif bir ayırımcılıkla korumalıdır. Medya kuruluşları, bu amaçla sürdürülen çalışmaları daha ileri boyutlara taşıyarak, ulusal ve uluslararası düzenlemelerde ifadesini bulan cinsiyetler arası eşitlik idealini hayata geçirmek için alanına giren sorumlulukları yerine getirmelidir. Medya çalışanları özellikle kadına yönelik olarak gerçekleşen şiddet olaylarını haberleştirirken şu hususlara özen göstermeleri beklenir:

- Cinsiyet ayırımcılığına dayalı şiddet haberleri hiç bir şekilde meşru gösterilmemeli

- Mağdurun kimliğinin tespitine yarayacak ip uçlarının verilmemesine özen gösterilmeli

- Röportajı, ya da haberi yayınlanacak olan kişiden veya onun yasal temsilcilerinden zamanında gerekli izin ve onaylar alınmalı

- Şiddet mağdurlarının şeref, haysiyet, aile birliği, mesleki konumu ve sosyal çevresinin korunması için gerekli özen gösterilmeli

- Mağdur kadınlar ve yakınları ile ilgili olarak yayınlanacak olan görsellerde seçici ve dikkatli davranılmalı

- Özellikle tarafı kadın olan mağdurların haberleştirilmesinde kullanılacak olan dil özenle seçilmeli hatta mümkünse olayın detaylarını gizleyerek, suça yönlendirici yeni bir yola, yönteme zemin hazırlamamalıdır.

\section{Çalışmanın Yöntemi}

Ülkemizde çocuk hak haberciliğinin en iyi koşullarda yerine getirilebilmesinin yanı sıra, kadın-erkek nüfus dengesinin hiç değilse medyada gözetilmesi ve buna uygun haber ve içerik üretilmesi beklenmektedir.

Medyada yer alan haberler özellikle kadın ve çocuk şiddet, taciz, tecavüz ve cinayet haberleri kapsamında toplumsal farkındalığı artırmak için yapılan haberler olmasının yanı sıra habere konu olan tarafların yeni medya anlayışı çerçevesinde 
reyting uğruna etik kurallar çiğnenerek habere dâhil edilmeleri nedeniyle medya ve etik kuralları açısından tartışılması gerekli önemli hususların ele alınarak bu konuda geliştirilecek olan "yeni haber dili”nin nasıl olması gerektiği konusundaki görüş ve öneriler paylaşlacaktır.

Araştırmada, genel olarak medya araştırmalarında uygulanan "eleştirel söylem analizi" yöntemi ve buna bağlı yöntemler uygulanmıştır. İncelenen örneklerin özellikleri doğrultusunda 4 başlık altında bu çalışma sonuçlarını değerlendirme söz konusudur;

1. Yazınsal/sözsel, gerektiğinde ikonografik (fotoğraf, resim ve diğer çizimlere ilişkin) ve metin analizleri gerçekleștirilmiştir.

2. Medya içerikleri ve söylem konusunda, belli göstergeler oluşturmak amacıyla niceliksel ölçeklemeye başvurulmuş olsa da; bu teknik, genel olarak niteliksel olan araștırma amacı doğrultusunda klasik içerik analizlerinde uygulanan salt niceliksel tekniklerden farklıdır.

3. Gazete ve internet siteleri açısından hesaplamaları dikkate alınmamıştır. Buna karşılık, kadınların ve çocukların temsil biçimlerinin yanı sıra içeriğin bütünü içindeki “önem”lerini ortaya çıkarmak amacıyla niteliksel amaçlı bir ağırlıklandırma yapılmıştır. Bu işleme ilişkin ayrıntılar, aşağıda "çözümleme" bölümünde yer almaktadır. Bütünsel olarak ele alındığında, çalışma, niceliksel göstergeler de içeren niteliksel bir araştırmadır.

4. Fakültemizde ilgili alanlarda verdiğimiz derslerde alınan geri dönüşler ve paylaşılan içerikler yapılan çalışmalarla belli başlıklar altında toplanarak değerlendirilmiş, öğrencilerin de desteği sağlanarak eğitim-öğretim döneminin başlangıcı olan 2017 yılı Eylül ayı ve 2018 yılı Ekim ayı (ilk 10 günü dahil olmak üzere) arasındaki toplam 405 günde sosyal medya, internet medyası, gazete, televizyon, radyo ve dergi olmak üzere 6 mecrada 6 farklı soru; rastgele seçilen 125 erkek ve 125 kadın toplam 250 katılımcıya önce "Çocuk Odaklı Habercilik“ daha sonra ise "Kadın Odaklı Habercilik" başlıklı formlar sunularak alınan cevaplar işlenmiştir.

5. Başlangıçta daha kalabalık bir katılımcı grubu, daha detaylı bir medya mecrası ve çok sayıda soru ile başlamış olduğumuz çalışma, ölçek belirleme esasları gözden geçirildikten sonra bazı örneklemeler de dikkate alınarak kapsam daraltılmış ve 250 katılımcı ve 6 adet soru, 6 medya mecrası biçiminde sınırlandırılarak verilerin işlenmesi, değerlendirilmesi kolay ve

6. Sorulan 6 adetsoru; hem geleneksel ve hem de güncel dijital medyayı kapsayacak bir alan içinde "Sosyal Medya”, İnternet Medyası", “Gazete”, Televizyon”, “Radyo” ve "Dergi" ana başlıkları çerçevesinde "Haberlerde Çocuğun Temsile Eleştirel Bakış" ardından "Haberlerde Kadının Temsiline Eleştirel Bakış" başlıkları altında "Evet", "Hayır", "Fikrim Yok" biçiminde verilen cevaplar dikkate alınmıştır.

7. Çok fazla veri içermesi nedeniyle mümkün oldukça çalışmanın ana hatlarını etkilemeyecek biçimde az sayıda tablo ile yorumlanmaya çalışılmıştır.

8. Ayrıca bu çalışmanın verilerinin kaynağı olan medya ürünleri için karşılaştırmalı sayısal verileri içeren ayrı bir tablo içerisinde değerlendirme yapılmıştır. 


\section{Elde Edilen Bulgular ve Yorumlanması}

\section{Haberlerde Çocuğun Temsiline Eleştirel Bakış - Çocuk Odaklı Habercilik Araştırması}

İlgili Dönemi Kapsayan 405 Günlük Süre İçerisinde Tekrarlar ve Kısıtlamalar Gözetilerek Taraması Yapılan Medya Ürünlerinde Çocuğa İlişkin Elde Edilen Sayısal Veriler aşağıda sunulmuştur.

Tablo 2: Tablo Adı?

\begin{tabular}{|l|c|c|c|c|c|c|}
\hline & $\begin{array}{c}\text { Sosyal } \\
\text { Medya }\end{array}$ & $\begin{array}{c}\text { İntermet } \\
\text { Medyası }\end{array}$ & Gazete & Televizyon & Radyo & Dergi \\
\hline $\begin{array}{l}\text { Çocuk Başlıklı Taciz- } \\
\text { Tecavüz-Şiddet Vb. } \\
\text { Olumsuz Haberler }\end{array}$ & 550 & 632 & 210 & 105 & 70 & 15 \\
\hline $\begin{array}{l}\text { Çocuk Başlıklı Eğitim- } \\
\text { Kültür-Sanat-Başarı } \\
\text { Vb. Olumlu Haberler }\end{array}$ & 212 & 346 & 170 & 80 & 55 & 10 \\
\hline Diğer & 70 & 106 & 100 & 15 & 5 & 5 \\
\hline
\end{tabular}

**1. Soru: Medyada çocuğa yönelik şiddet haberlerinin sunum biçimi sizce uygun mudur?

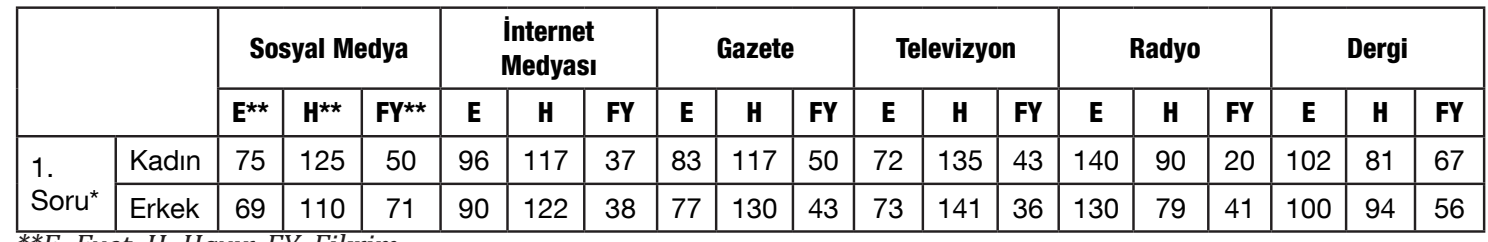

**E: Evet, H: Hayır, FY: Fikrim

**2. Soru: Medyada çocuğa yönelik olarak sunulan haberlerde bir "sıradanlaşma" izlenimi ediniyor musunuz?

\begin{tabular}{|c|c|c|c|c|c|c|c|c|c|c|c|c|c|c|c|c|c|c|c|}
\hline & & \multicolumn{3}{|c|}{ Sosyal Medya } & \multicolumn{3}{|c|}{ İnternet Medyası } & \multicolumn{3}{|c|}{ Gazete } & \multicolumn{3}{|c|}{ Televizyon } & \multicolumn{3}{|c|}{ Radyo } & \multicolumn{3}{|c|}{ Dergi } \\
\hline & & $E^{\star \star}$ & $H^{\star \star}$ & $\mathbf{F} \mathbf{Y}^{\star \star}$ & E & H & FY & $\mathbf{E}$ & H & FY & E & H & $\mathbf{F Y}$ & E & H & $\mathbf{F Y}$ & $\mathbf{E}$ & H & $\mathbf{F Y}$ \\
\hline \multirow{2}{*}{$\begin{array}{l}2 . \\
\text { Soru* }\end{array}$} & Kadın & 151 & 75 & 24 & 153 & 74 & 23 & 125 & 97 & 28 & 138 & 86 & 26 & 112 & 99 & 39 & 133 & 75 & 42 \\
\hline & Erkek & 140 & 88 & 22 & 133 & 92 & 25 & 117 & 90 & 43 & 130 & 80 & 40 & 139 & 80 & 31 & 125 & 80 & 45 \\
\hline
\end{tabular}

**3. Soru: Medyada çocuğa yönelik verilen haberlerde "şiddetin özendirilmesi ve meşrulaştırılması" söz konusu mudur?

\begin{tabular}{|c|c|c|c|c|c|c|c|c|c|c|c|c|c|c|c|c|c|c|c|}
\hline & & \multicolumn{3}{|c|}{ Sosyal Medya } & \multicolumn{3}{|c|}{$\begin{array}{l}\text { İnternet } \\
\text { Medyası }\end{array}$} & \multicolumn{3}{|c|}{ Gazete } & \multicolumn{3}{|c|}{ Televizyon } & \multicolumn{3}{|c|}{ Radyo } & \multicolumn{3}{|c|}{ Dergi } \\
\hline & & $E^{\star \star}$ & $H^{\star \star}$ & $F Y * *$ & $\mathbf{E}$ & H & FY & $\mathbf{E}$ & H & FY & $\mathbf{E}$ & H & $\mathbf{F Y}$ & $\mathbf{E}$ & H & FY & $\mathbf{E}$ & H & FY \\
\hline \multirow{2}{*}{$\begin{array}{l}3 . \\
\text { Soru* }\end{array}$} & Kadın & 165 & 50 & 35 & 150 & 67 & 33 & 143 & 71 & 36 & 140 & 76 & 34 & 133 & 100 & 17 & 115 & 85 & 50 \\
\hline & Erkek & 144 & 75 & 31 & 138 & 91 & 21 & 150 & 81 & 19 & 116 & 90 & 44 & 122 & 100 & 28 & 140 & 78 & 32 \\
\hline
\end{tabular}

**E: Evet, H: Hayır, FY: Fikrim Yok

**4. Soru: Medyada çocuğa yönelik olarak sunulan şiddet haberleri sizde sosyal sorumluluk ve hak haberciliği bağlamında farkındalık düşüncesi oluşturuyor mu?

\begin{tabular}{|c|c|c|c|c|c|c|c|c|c|c|c|c|c|c|c|c|c|c|c|}
\hline & & \multicolumn{3}{|c|}{ Sosyal Medya } & \multicolumn{3}{|c|}{$\begin{array}{l}\text { İnternet } \\
\text { Medyası }\end{array}$} & \multicolumn{3}{|c|}{ Gazete } & \multicolumn{3}{|c|}{ Televizyon } & \multicolumn{3}{|c|}{ Radyo } & \multicolumn{3}{|c|}{ Dergi } \\
\hline & & $E^{\star \star}$ & $H^{\star \star}$ & $\mathbf{F Y}^{\star \star \star}$ & E & H & FY & E & H & FY & E & H & FY & E & H & FY & E & H & $\mathbf{F Y}$ \\
\hline \multirow{2}{*}{$\begin{array}{l}4 . \\
\text { Soru* }\end{array}$} & Kadın & 100 & 75 & 75 & 80 & 115 & 55 & 108 & 85 & 57 & 85 & 110 & 55 & 117 & 100 & 33 & 106 & 100 & 44 \\
\hline & Erkek & 109 & 90 & 51 & 92 & 100 & 87 & 100 & 109 & 41 & 93 & 127 & 30 & 102 & 110 & 38 & 87 & 93 & 70 \\
\hline
\end{tabular}

${ }^{* *}$ E: Evet, H: Hayır, FY: Fikrim Yok 
**5. Soru: Medyada çocuğa yönelik olarak hazırlanan ve sunulan haberlerin içeriği "sizce" sorunun çözümüne katkı sağlıyor mu?

\begin{tabular}{|c|c|c|c|c|c|c|c|c|c|c|c|c|c|c|c|c|c|c|c|}
\hline & \multicolumn{3}{|c|}{ Sosyal Medya } & \multicolumn{3}{|c|}{$\begin{array}{l}\text { İnternet } \\
\text { Medyası }\end{array}$} & \multicolumn{3}{|c|}{ Gazete } & \multicolumn{3}{|c|}{ Televizyon } & \multicolumn{3}{|c|}{ Radyo } & \multicolumn{3}{|c|}{ Dergi } \\
\hline & & $E^{\star \star}$ & $H^{\star \star}$ & $\mathbf{F Y} \mathbf{Y}^{\star \star}$ & E & H & FY & E & H & $\mathbf{F Y}$ & $\mathbf{E}$ & H & FY & E & H & $\mathbf{F Y}$ & $\mathbf{E}$ & H & FY \\
\hline \multirow{2}{*}{$\begin{array}{l}5 . \\
\text { Soru* }\end{array}$} & Kadın & 77 & 135 & 38 & 83 & 140 & 27 & 81 & 136 & 33 & 75 & 120 & 55 & 92 & 135 & 23 & 80 & 105 & 65 \\
\hline & Erkek & 83 & 125 & 42 & 80 & 116 & 54 & 96 & 115 & 39 & 70 & 115 & 65 & 86 & 111 & 53 & 71 & 123 & 56 \\
\hline
\end{tabular}

**E: Evet, H: Hayır, FY: Fikrim Yok

**6. Soru: Medyada çocuğa yönelik olarak sunulan haberlerde kullanılan dil, yöntem ve süre sizce uygun mudur?

\begin{tabular}{|c|c|c|c|c|c|c|c|c|c|c|c|c|c|c|c|c|c|c|c|}
\hline & \multicolumn{3}{|c|}{ Sosyal Medya } & \multicolumn{3}{|c|}{$\begin{array}{l}\text { Internet } \\
\text { Medyası }\end{array}$} & \multicolumn{3}{|c|}{ Gazete } & \multicolumn{3}{|c|}{ Televizyon } & \multicolumn{3}{|c|}{ Radyo } & \multicolumn{3}{|c|}{ Dergi } \\
\hline & & $E^{\star \star}$ & $H^{\star \star}$ & $\mathbf{F Y}^{\star \star *}$ & E & H & FY & E & H & FY & E & H & FY & E & H & FY & E & H & FY \\
\hline \multirow{2}{*}{$\begin{array}{l}6 . \\
\text { Soru* }\end{array}$} & Kadın & 85 & 140 & 25 & 91 & 136 & 23 & 79 & 130 & 41 & 86 & 132 & 32 & 90 & 125 & 35 & 66 & 130 & 54 \\
\hline & Erkek & 77 & 135 & 38 & 83 & 127 & 40 & 90 & 122 & 38 & 69 & 127 & 54 & 96 & 118 & 36 & 70 & 120 & 60 \\
\hline
\end{tabular}

${ }^{* *}$ E: Evet, H: Hayır, FY: Fikrim Yok

Bu araştırıma sonuçlarını irdeleyecek olursak özellikle kadınların verilen cevaplarda konuya yaklaşım açısından daha duyarlı davrandıklarını söylemek mümkündür. Ayrıca sayısal verilerin topluca değerlendirmesi yapıldığında da birbirine yakın sonuçların çıktığını görmekteyiz.

Yukarıdaki tablodan hareketle; öncelikle medyada çocuğun temsiline ilişkin olarak yapılan sayısal değerlendirmede elde edilen sonuçlar bize her iki başlık altında açılan kadın ve erkeğe yöneltilen 6 adet soruya benzer yakınlıkta cevaplar verildiğini göstermektedir.

- Çocuk konusunda;

1. Soruya (Medyada çocuğa yönelik şiddet haberlerinin sunum biçimi sizce uygun mudur?),

3. Soruya (Medyada çocuğa yönelik verilen haberlerde "şiddetin özendirilmesi ve meşrulaştırılması" söz konusu mudur?) ve

6. Soruya (Medyada çocuğa yönelik olarak sunulan haberlerde kullanılan dil, yöntem ve süre sizce uygun mudur?)

\section{Haberlerde Kadının Temsiline Eleştirel Bakış - Kadın Odaklı Habercilik Araştırması}

İlgili Dönemi Kapsayan 405 Günlük Süre İçerisinde Tekrarlar ve Kısıtlamalar Gözetilerek Taraması Yapılan Medya Ürünlerinde Kadına İlişkin Elde Edilen Sayısal Veriler aşağıda sunulmuştur.

Tablo 3: Tablo Adı?

\begin{tabular}{|l|c|c|c|c|c|c|}
\hline & Sosyal Medya & İntermet Medyası & Gazete & Televizyon & Radyo & Dergi \\
\hline $\begin{array}{l}\text { Kadın Başlıklı Taciz- } \\
\text { Tecavüz-Şiddet Vb. } \\
\text { Olumsuz Haberler }\end{array}$ & 715 & 1110 & 316 & 244 & 120 & 40 \\
\hline $\begin{array}{l}\text { Kadın Başlıklı Eğitim- } \\
\text { Kültür-Sanat-Başarı } \\
\text { Vb. Olumlu Haberler }\end{array}$ & 503 & 1060 & 205 & 124 & 75 & 25 \\
\hline Diğer & 109 & 210 & 95 & 20 & 15 & 10 \\
\hline
\end{tabular}


**1. Soru: Medyada kadına yönelik şiddet haberlerinin sunum biçimi sizce uygun mudur?

\begin{tabular}{|c|c|c|c|c|c|c|c|c|c|c|c|c|c|c|c|c|c|c|c|}
\hline & \multicolumn{3}{|c|}{ Sosyal Medya } & \multicolumn{3}{|c|}{$\begin{array}{l}\text { İnternet } \\
\text { Medyası }\end{array}$} & \multicolumn{3}{|c|}{ Gazete } & \multicolumn{3}{|c|}{ Televizyon } & \multicolumn{3}{|c|}{ Radyo } & \multicolumn{3}{|c|}{ Dergi } \\
\hline & & $E^{\star \star}$ & $H^{\star \star}$ & $F Y^{\star *}$ & $\mathbf{E}$ & H & FY & $\mathbf{E}$ & H & $\mathbf{F Y}$ & E & H & $\mathbf{F Y}$ & $\mathbf{E}$ & H & FY & E & H & $\mathbf{F Y}$ \\
\hline \multirow{2}{*}{$\begin{array}{l}1 . \\
\text { Soru* }\end{array}$} & Kadın & 70 & 130 & 50 & 89 & 115 & 46 & 78 & 110 & 62 & 65 & 130 & 55 & 133 & 85 & 32 & 110 & 75 & 65 \\
\hline & Erkek & 69 & 126 & 55 & 81 & 119 & 50 & 69 & 121 & 60 & 67 & 136 & 47 & 127 & 80 & 43 & 98 & 95 & 57 \\
\hline
\end{tabular}

${ }^{* *}$ E: Evet, H: Hayır, FY: Fikrim Yok

**2. Soru: Medyada kadına yönelik olarak sunulan haberlerde bir "sıradanlaşma" izlenimi ediniyor musunuz?

\begin{tabular}{|c|c|c|c|c|c|c|c|c|c|c|c|c|c|c|c|c|c|c|c|}
\hline & \multicolumn{3}{|c|}{ Sosyal Medya } & \multicolumn{3}{|c|}{$\begin{array}{l}\text { Internet } \\
\text { Medyas }\end{array}$} & \multicolumn{3}{|c|}{ Gazete } & \multicolumn{3}{|c|}{ Televizyon } & \multicolumn{3}{|c|}{ Radyo } & \multicolumn{3}{|c|}{ Dergi } \\
\hline & & $E^{\star \star}$ & $\mathrm{H}^{\star \star}$ & $F Y \star \star$ & E & H & FY & $\mathbf{E}$ & H & FY & $\mathbf{E}$ & H & $\mathbf{F Y}$ & $\mathbf{E}$ & H & FY & E & H & FY \\
\hline \multirow{2}{*}{$\begin{array}{l}2 . \\
\text { Soru* }\end{array}$} & Kadın & 145 & 70 & 35 & 140 & 82 & 28 & 112 & 100 & 38 & 126 & 90 & 34 & 108 & 101 & 41 & 130 & 81 & 39 \\
\hline & Erkek & 136 & 90 & 24 & 126 & 90 & 34 & 111 & 99 & 40 & 121 & 92 & 37 & 123 & 92 & 35 & 119 & 76 & 55 \\
\hline
\end{tabular}

${ }^{* *}$ E: Evet, H: Hayır, FY: Fikrim Yok

**3. Soru: Medyada kadına yönelik verilen haberlerde "şiddetin özendirilmesi ve meşrulaştırılması" söz konusu mudur?

\begin{tabular}{|c|c|c|c|c|c|c|c|c|c|c|c|c|c|c|c|c|c|c|c|}
\hline & & \multicolumn{3}{|c|}{ Sosyal Medya } & \multicolumn{3}{|c|}{$\begin{array}{l}\text { İnternet } \\
\text { Medyası }\end{array}$} & \multicolumn{3}{|c|}{ Gazete } & \multicolumn{3}{|c|}{ Televizyon } & \multicolumn{3}{|c|}{ Radyo } & \multicolumn{3}{|c|}{ Dergi } \\
\hline & & $E^{\star \star}$ & $H^{\star \star}$ & $\mathbf{F Y} * \star$ & $\mathbf{E}$ & H & $\mathbf{F Y}$ & $\mathbf{E}$ & H & $\mathbf{F Y}$ & $\mathbf{E}$ & H & FY & $\mathbf{E}$ & H & $\mathbf{F Y}$ & E & H & FY \\
\hline \multirow{2}{*}{$\begin{array}{l}3 . \\
\text { Soru* }\end{array}$} & Kadın & 155 & 70 & 25 & 145 & 70 & 35 & 135 & 80 & 35 & 139 & 66 & 45 & 133 & 101 & 16 & 125 & 80 & 45 \\
\hline & Erkek & 132 & 83 & 35 & 141 & 85 & 24 & 144 & 82 & 24 & 110 & 100 & 40 & 117 & 94 & 39 & 140 & 78 & 32 \\
\hline
\end{tabular}

${ }^{* *}$ E: Evet, H: Hayır, FY: Fikrim Yok

**4. Soru: Medyada kadına yönelik olarak sunulan şiddet haberleri sizde sosyal sorumluluk ve hak haberciliği bağlamında farkındalık düşüncesi oluşturuyor mu?

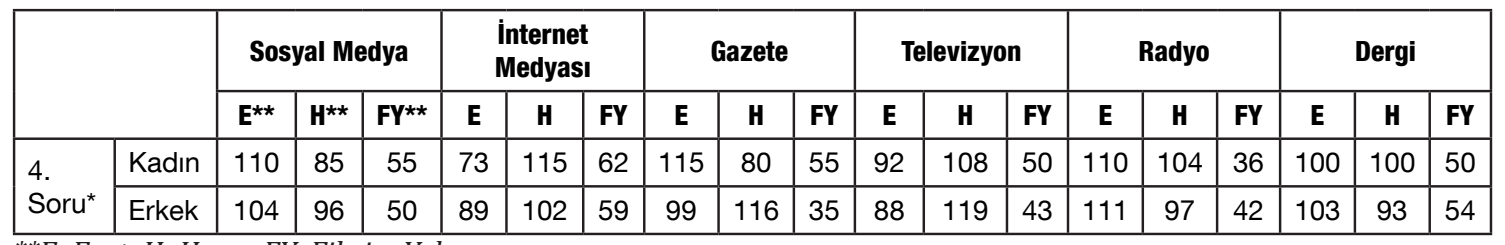

${ }^{* *}$ E: Evet, H: Hayır, FY: Fikrim Yok

**5. Soru: Medyada kadına yönelik olarak hazırlanan ve sunulan haberlerin içeriği "sizce" sorunun çözümüne katkı sağlıyor mu?

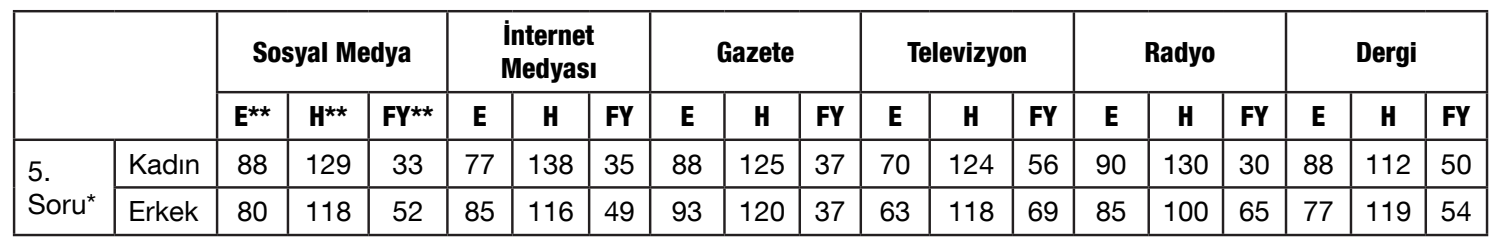

${ }^{* *}$ E: Evet, H: Hayır, FY: Fikrim Yok 
**6. Soru: Medyada kadına yönelik olarak sunulan haberlerde kullanılan dil, yöntem ve süre sizce uygun mudur?

\begin{tabular}{|c|c|c|c|c|c|c|c|c|c|c|c|c|c|c|c|c|c|c|}
\hline & \multicolumn{3}{|c|}{ Sosyal Medya } & \multicolumn{3}{|c|}{ Internet Medyası } & \multicolumn{3}{|c|}{ Gazete } & \multicolumn{3}{|c|}{ Televizyon } & \multicolumn{3}{|c|}{ Radyo } & \multicolumn{2}{|c|}{ Dergi } \\
\hline & & $E^{\star \star}$ & $H^{\star \star}$ & $F^{* \star *}$ & E & H & FY & E & H & FY & E & H & FY & E & H & FY & E & H \\
\hline \multirow{2}{*}{$\begin{array}{l}6 . \\
\text { Soru* }\end{array}$} & Kadın & 77 & 130 & 43 & 83 & 120 & 47 & 80 & 130 & 40 & 80 & 120 & 50 & 87 & 125 & 38 & 65 & 140 \\
\hline & Erkek & 87 & 119 & 44 & 90 & 127 & 33 & 78 & 123 & 49 & 77 & 120 & 53 & 90 & 123 & 37 & 82 & 126 \\
\hline
\end{tabular}

**E: Evet, H: Hayır, FY: Fikrim Yok

Aynı şekilde bu araştırmada da sonuçlar irdelenecek olursa; özellikle kadınların verilen cevaplarda konuya yaklaşım açısından daha duyarlı davrandıklarını söylemek mümkündür. Ayrıca sayısal verilerin topluca değerlendirmesi yapıldığında da birbirine yakın sonuçların çıktığını görmekteyiz.

Yukarıdaki tablodan hareketle; öncelikle medyada kadının temsiline ilişkin olarak yapılan sayısal değerlendirmede elde edilen sonuçlar bize her iki başlık altında açılan kadın ve erkeğe yöneltilen 6 adet soruya benzer yakınlıkta cevaplar verildiğini göstermektedir.

- Kadın konusunda;

1. Soruya (Medyada kadına yönelik şiddet haberlerinin sunum biçimi sizce uygun mudur?),

3. Soruya (Medyada kadına yönelik verilen haberlerde "şiddetin özendirilmesi ve meşrulaştırılması" söz konusu mudur?) ve

6. Soruya (Medyada kadına yönelik olarak sunulan haberlerde kullanılan dil, yöntem ve süre sizce uygun mudur?)

Verilen tüm cevaplar aşağıda örneklem tablolar halinde gösterilen oransal bir yakınlık ve benzerlik gösterdiğinden dolayı bize; medyada bu gibi konularda aynı başlık altında açılan konulara aynı hassasiyetin gösterildiği izlenimini sunmaktadır.

\section{Sonuç}

\section{Medya ve Çocuk}

Medya normal ve anormal çocuk imgeleri üzerinden ürettiği anlamlar ile toplumsal algıya yön vermektedir. Çocuk temsilleri üzerinden medyanın dilini incelemek temelde bu dilin ideolojik kodlarını çözmenin en basit imkânlarını sunduğu için değerlidir. Çünkü çocuk neslin devamı olduğu gibi onun yetiştirilme biçimi ideolojinin en açık olarak görülebileceği alandır. İdeolojinin doğrudan ve en saf haliyle görüleceği bu alanı medya üzerinden incelediğimizde, medyanın amacını ortaya koymak mümkün olacaktır.

- Sosyolojik çalışmalarda çocukların ele alınmasına benzer bir yaklaşımı medya incelemelerinde de görmek mümkündür. Medya çalışmaları yapan araştırmacılar genellikle çocuğu medyanın olumsuz etkilerinden koruma veya çocuğun medyadan etkilenmesine odaklanmaktadır

- Medyanın çocukları genellikle mağdur olarak haberlere konu etmesindeki amaçların, bazı problemler konusunda toplumu ikna etmek ve kendi izlenirliğini artırmak olduğunu söylemek mümkündür

- Çocuk temsilleri ayırımını yaparken iyi çocuk, kötü çocuk ve mağdur çocuk gibi bir dağılım bizi asıl konudan uzaklaştırırken çözümü de zorlaştırır 
- Medya ürünleri temelde toplumsal temsiller aracılığıyla üretilmektedir. Bu ürünler, içinden çıktıkları toplumun değerleri ve toplumsal süreçleriyle anlamlı hale gelmektedir. $\mathrm{Bu}$ nedenle, temsil toplumsal yapıyla doğrudan ilişkilidir. $\mathrm{Bu}$ temsilleri çocuktan bağımsız düşünmek anlamsızdır

- Geleneksel olarak, çocuklara toplumun korunması gereken bir alt grubu olarak bakılmaktadır. Çocuklara yönelik yapılacak olan tehdit, taciz, şiddet vb. eylemler onlarda çok güçlü karşı bir duygusal tepkiye yol açar. Bu nedenle onlarla ilgili haber ve görüntüler bu anlamıyla kendine özgü bir potansiyel değer ve önem taşırlar

- Çocukların masumiyeti bazen evrensel bir yanılgıyı da beraberinde getiriri öyle ki; onların bu masumiyeti, şirinliği, haylazlığı onlara karşı yetişkinlerin daha duyarlı ve yeri geldiğinde hak ihlallerine karşı en sert duruşu da beraberinde getirir

- Çocuk, medyanın sanal ortamında kurguladığı "şirin ve zavallı mağdur" olmaktan kurtarılarak "yurttaş" olma yolunda bilinçli bir birey olmaya yönlendirilmelidir.

\section{Medya ve Kadın}

Özellikle kadına yönelik şiddetin temelinde toplumsal cinsiyet eşitliğinin bulunmaması yatmaktadır. Hatta bu şiddet suçunun işlenmesi planlı, ideolojik, sistematik ve politik bir biçimde yapılmakta ve onaylatmak adına doğrudan medyaya yansıtılmaktadır. Medyadan, bu suçun ortağı olması değil, aksine sosyal sorumluluk ve insan haklarının ihmal edilmemesi anlayışı ile hareket etmesi beklenmektedir. Çünkü kadın, ataerkil egemenliğine direnç gösterdiği andan itibaren en yakınındaki erkekten şiddet görmekte, ya ölmekte ya zinciri kırıp kendine sığınacak bir yer bulmakta ya da çaresizlikle suskunlaşmaktadır. Bu nedenle;

- Haberlerde ve diğer ana gündem maddelerinde kadınların temsil biçimi yeniden düzenlenmeli,

- Kadının doğasına uygun olarak medyada ona hitap edilirken; eş, anne, magazin objesi, cinsellik objesi , çalışan kadın, sosyal varlık vb. tüm tanımlamalarda pozitif ayrımcılık gözetilerek konu ele alınmalı,

- İçerik üretiminde kadınların azınlığına son verilmeli,

- Kadınlarla birlikte hareket edilerek, görece daha yüksek oranlarda temsil edildiklerinde bile ortaya çıkan ürünlerdeki cinsiyetçi kalıpların kırılamamış olması, genel olarak bu alanlardaki mesleki pratiklerin ve topyekun söylemin içerdiği cinsiyetçiliğin gündelik rutin içinde kadınlar tarafından bile içselleştirildiğini ortaya koymaktadır. Dolayısıyla "cinsiyetçi olmayan bir medya" için geliştirilecek politikalar ve eylem planlarında, mevcut durumun teşhis ve teşhiri aracılığıyla duyarlılık oluşturmanın yanı sıra, öncelikle kadınların pek az yer aldıkları yönetim kademeleri nezdinde, buna koşut olarak da medyada halen farklı alan ve kademelerde çalışmakta olan kadınlarla birlikte yürütülecek çalışmalar özendirilmelidir (Tanrı̈̈ver, 2008,123).

Elde edilen tüm bulgular bütünsel olarak değerlendirildiklerinde, bugüne kadar bu mecraların ve incelenen örnek programların her biri üzerine yapılan bilimsel araştırmaların bulgularını doğrular bir sonuç ortaya çıkmaktadır. Medyanın genelinde çocukların aleyhine yok sayma ve kadınların aleyhine ise cinsiyetçi bir söylem egemendir.

Metinlerin içeriklerine bakıldığında, haber metinlerinde çocukların kadınlara 
oranla daha az yer aldığı ancak temsil biçimleri incelendiğinde, haberin temel öznesi olarak ve yaşamın farklı alanlarında (eğitim, siyaset, ekonomi, iş yaşamı, vb.) özellikle erkeklerle eşit konumda asla temsil edilmedikleri gözlemlenmektedir. Tüm bu içeriklerin üretim mekanizmalarına bakıldığında, özellikle kadınların doğrudan "üretim" düzeyinde, bazı medyalarda geçmiş yıllara oranla görece daha yüksek oranlarda mevcut oldukları görülmüştür. Ancak bu noktada da yatay ve dikey ayrımcılığın halen ciddi biçimde varlığını sürdürdüğü görülmektedir. Çocuklar için ise maalesef aynı düşünceyi paylaşmak mümkün görünmemektedir. Gerek dünyanın ve gerekse ülkemiz nüfusunun çok büyük bir kısmını oluşturan çocukların medyada çok az ve ancak adli olay bazlı haberlerle yer alması da ayrıca eleștirilmesi gereken bir durumdur.

\section{Kaynakça}

Aktaş, C., 2007, Yeni Medyanın Geleneksel Medya İle Karşılaştırılması 'Medya Üzerine Çalışmalar. G. Erol (Der). İstanbul: Beta Yayınları.

Alankuş, S., Önsöz, (2012), Neden Çocuk Odaklı Habercilik Kitabı?, Çocuk Odaklı Habercilik, İstanbul, IPS İletişim Vakfı yayınları 11, Hak Haberciliği Dizisi,

Atabek, N., (2006), Gazete Haberlerinde Etik Standartların Yükseltilmesinde Okur Temsilcisinin Rolü. Selçuk İletişim Fakültesi, Küresel İletişim Dergisi, (S. 2-Güz), s.1-14,

Aufderheide, P., (1993). "Media Literacy: A Report of The National Leadership Conference on Media Literacy." Washington, DC, Aspen Institute.

Barut, E., Koç, M., (2016), "Yeni Medya Okuryazarlığı”, 33. Bölüm, Eğitim Teknolojileri Okumaları, TOJET, Sakarya Üniversitesi Yayınları, Ankara, s. 595-613

Baran, A.G., Sarıtaş, C.B., Kütük, B.Ş., (2017), "Medyada Kadına Yönelik Şiddet Haberlerinin İçerik ve Sunum Açısından Analizi: Beyazgazete.com Örneği”, Sosyoloji Konferansları Dergisi, No. (55), (2017-1), s. 107-132

Bek, M.G., (2011), Medyada Çocuk Hakları ve Etik İlkeler, 1. Türkiye Çocuk Hakları Kongresi, Çocuk Hakları ve Medya El Kitabı, M. R. Şahin, (Haz.) İstanbul, Çocuk Vakfı Yayınları, No.88, Yay Dizisi No. 13

Binark, M., Bayraktutan, G., (2013), Ayın Karanlık Yüzü: YENİ MEDYA VE ETIK, İstanbul, Kalkedon Yayıncılık

Binark, M. ve Bek, M.G., (2007), Eleştirel Medya Okuryazarlığı: Kuramsal Yaklaşımlar ve Uygulamalar, İstanbul: Kalkedon Yayınları,

Çakır, H., Gazete Haberlerinde Okur Temsilcisinin Rolü Üzerine Karşılaştırmalı Bir İnceleme, Manas Sosyal Araştırmalar Dergisi, cilt (6), s.1, sayfa 63-75, 2017, Manas

Kitzinger, J.,(1988). Defending Innocence: Ideologies of Childhood. Feminist Review, 28, 77-87.

Mora, N.(2014), Gençlerde Medya Bağımlılığı, İ\&D -İletişim ve Diplomasi- Dergisi, S.2, T.C. Başbakanlık Basın-Yayın ve Enformasyon Genel Müdürlüğü, Ankara

Orhon, N., (2011), Çocuklar İçin Eleştirel Medya Okuryazarlığı, 1. Türkiye Çocuk Hakları Kongresi, Çocuk Hakları ve Medya El Kitabı, M. R. Şahin, (Haz.),İstanbul, Çocuk Vakfı Yayınları, No.88, Yay Dizisi No. 13 
Örs, F., (2016), Medya Etik “Medya-İletişim-Etik-Sunuş”. F.Örs (Ed.), İstanbul, Sentez Yayıncilık

Özgen, M., (2003), Basında Bir Özdenetim Uygulaması Olarak Ombudsman, İstanbul Üniversitesi İletişim Fakültesi Dergisi, Sayı (16), s. 27-34, , İstanbul

Radyo ve Televizyon Üst Kurulu, (2007) Medya Okuryazarlı̆̆ı Dersi Öğretmen El Kitabı, Ankara

Şirin, M.R., (2011), Çocuk Hakları ve Medya Üzerine Bir Ön Bakış, 1. Türkiye Çocuk Hakları Kongresi, Çocuk Hakları ve Medya El Kitabı, M. R. Şahin, (Haz.), İstanbul, Çocuk Vakfı Yayınları, No.(88), Yay Dizisi No. (13)

Tanrıöver, H.U., (2008), MEDİZ Projesi-Medyada Kadınların Temsil Biçimleri Araștırması, (İstanbul Bilgi Üniversitesi 3- 4 Mayıs 2008 “Cinsiyetçi Olmayan Bir Medya İçin" Konferansı), İstanbul

Türkiye Gazeteciler Cemiyeti, (2016), Kadın ve Medya. İstanbul

http://www.webbilge.net/kitle-iletisim-araclarinin-aile-uzerinde-etkisi/erişimtarihi 27.09.2018

https://www.researchgate.net/publication/264985377/download, erişim tarihi 26.09.2018

https://www.takvim.com.tr/guncel/2015/02/16/vahset-minibusu, erişim tarihi 28.09.2018

https://twitter.com/netfordergi, erişim tarihi 28.09.2018)

http: / / www.milliyet.com.tr / cocuk-haklari-sayfasi / o mbudsman / haberdetay/12.07.2010/1262334/default.htm-erişim tarihi:02.10.2018

http://www.hurriyet.com.tr/gundem/evli-cocuklarla-ilgili-flas-gelisme-40938852erişim tarihi:02.10.2018

https://www.haber46.com.tr/guncel/kocasini-olduren-kadinin-ailesine-intikambombasi-h111335.html-erişim tarihi:02.10.2018 
